\title{
Thirty years of change in the fynbos vegetation of the Cape of Good Hope Nature Reserve, South Africa
}

\author{
S.D.J. PRIVETT *†, R.M. COWLING* and H.C. TAYLOR**
}

Keywords: fire effects, fynbos, succession, temporal change, vegetation monitoring

\section{ABSTRACT}

\begin{abstract}
This study used permanently marked $50 \mathrm{~m}^{2}$ sites, surveyed at a 30 year interval, to provide a descriptive account of the temporal change in the fynbos vegetation of the Cape of Good Hope Nature Reserve. South Africa. Management records were used to examine the role of post-fire age, fire frequency and intensity, as well as biotic interactions (competition from overstorey proteoids and alien plants) in influencing vegetation composition over this time period. The mean similarity in species composition of sites between surveys was $62 \%$, indicating an average of nearly $40 \%$ tumover in species over the 30 year period. The main causes of this change included differences resulting from different stages in the post-fire succession as well as the impact of differential fire regimes (especially frequency effects). Competition from serotinous Proteaceae, which proved highly mobile after fire, as well as invasive Australian acacias also impacted on the composition of the vegetation over time. The study demonstrated that fynbos communities are temporally dynamic and that the changes over time in species composition are caused by a variety of processes. The study also provided evidence for the role of temporal diversity in contributing to the high species diversity in fynbos systems.
\end{abstract}

CONTENTS

Introduction ....................... 99

Study area ...................... 101

Methods ..........................101

Results and discussion . . . . . . . . . . . . 102

1. Fire effects . . . . . . . . . . . . . . . . . 102

1.1. Post-fire succession ... . . . . . . . . . . 102

1.1.1. Early successional changes .......... 103

1.1.2. Successional changes after long fire-free intervals in upland fynbos ......... 103

1.1.3. Successional changes after long fire-free intervals in coastal fynbos . . . . . . . . . 105

1.2. Fire frequency ................. . 105

1.2.1. Short intervals between fires ... . . . . . . 106

1.2.2. Long intervals between fires . . . . . . . 106

2. Dynamics of serotinous Proteaceae . . . . . . 107

2.1. Causes of decline of serotinous Proteaceae . . 108

2.2. Causes of increase of serotinous Proteaceac . 108

2.3. The impact of serotinous Proteaceae on understorey species diversity

3. Alien plants

3.1. A comparison of the alien threat in 1966 and 1996

3.2. Impact of aliens on indigenous vegetation

3.2.1. Sites invaded between surveys and subsequently cleared

3.2.2. The impact of existing stands of alien plants

Conclusions

Acknowledgements .............. 112

References ................... 112

Appendix $1 \ldots \ldots \ldots \ldots \ldots \ldots \ldots \ldots \ldots \ldots . \ldots \ldots 14$

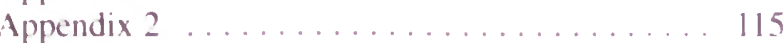

\footnotetext{
* Institule for Plant Consen ation. Botany Department. University of Cape Town. Private Bag. 77(x) Rondebosch. Cape Town

** Late, of the National Botanical Institute. Private Bag X7.7735 Clare mont. Cape Town

Present address: Groothes Nature Renerve. PO Box 148. 7220 Gans hatal. South Africa

MS received: $2(x)-(0) 2-15$
}

\section{INTRODUCTION}

'The ecological phenomena that we study often operate on temporal scales longer than our own existence and certainly longer than the time span of a research grant

Wiens ef al. (1986)

A major challenge facing vegetation scientists is to determine the resilience of communities, as well as individual species, to the varying components of the disturbance regime (Cowling 1987). Fire and invasion by alien plants are the major disturbance factors acting on the fynbos vegetation of the southern Cape Peninsula. South Africa. For practical reasons, studies on the effects of these disturbances on fynbos dynamics have always been temporally restricted. Studies on succession following fire have monitored recovery after a single fire event Similarly, the impacts of the various components of the fire regime on recruitment have looked at parent to seedling ratios at the same site following a single fire event (Bond 1980): Van Wilgen 1981: Hoffman et al. 1987: Cowling \& Gxaba 1990). These studies are limited as they base their results on single fire events. Most studies on the impact of alien plants on indigenous vegetation have compared adjacent invaded versus noninvaded sites (Richardson ef al. 1989: Holmes \& Cowling 1997), but see Richardson \& Van Wilgen (1985) for an exception. There is always the problem with this approach that differences in stands may reflect pre-existing differences in the physical environment and not the effects of fire or alien plants.

While many studies on decade-scale vegetation change have been undertaken internationally (e.g. Fojt \& Harding 1995: Rose ef al. 1995: Minnich ef al. 1995: Dodd e' al. 1995) and some local research has explored long-term changes in the semi-arid Karoo (Hoffman \& Cowling 1990: O'Connor \& Roux 1995), no work on medium-term temporal dynamics has been carried out in fynbos. Thus. while spatial patterns in the complex and diverse funbos vegetation have been extensively re- 


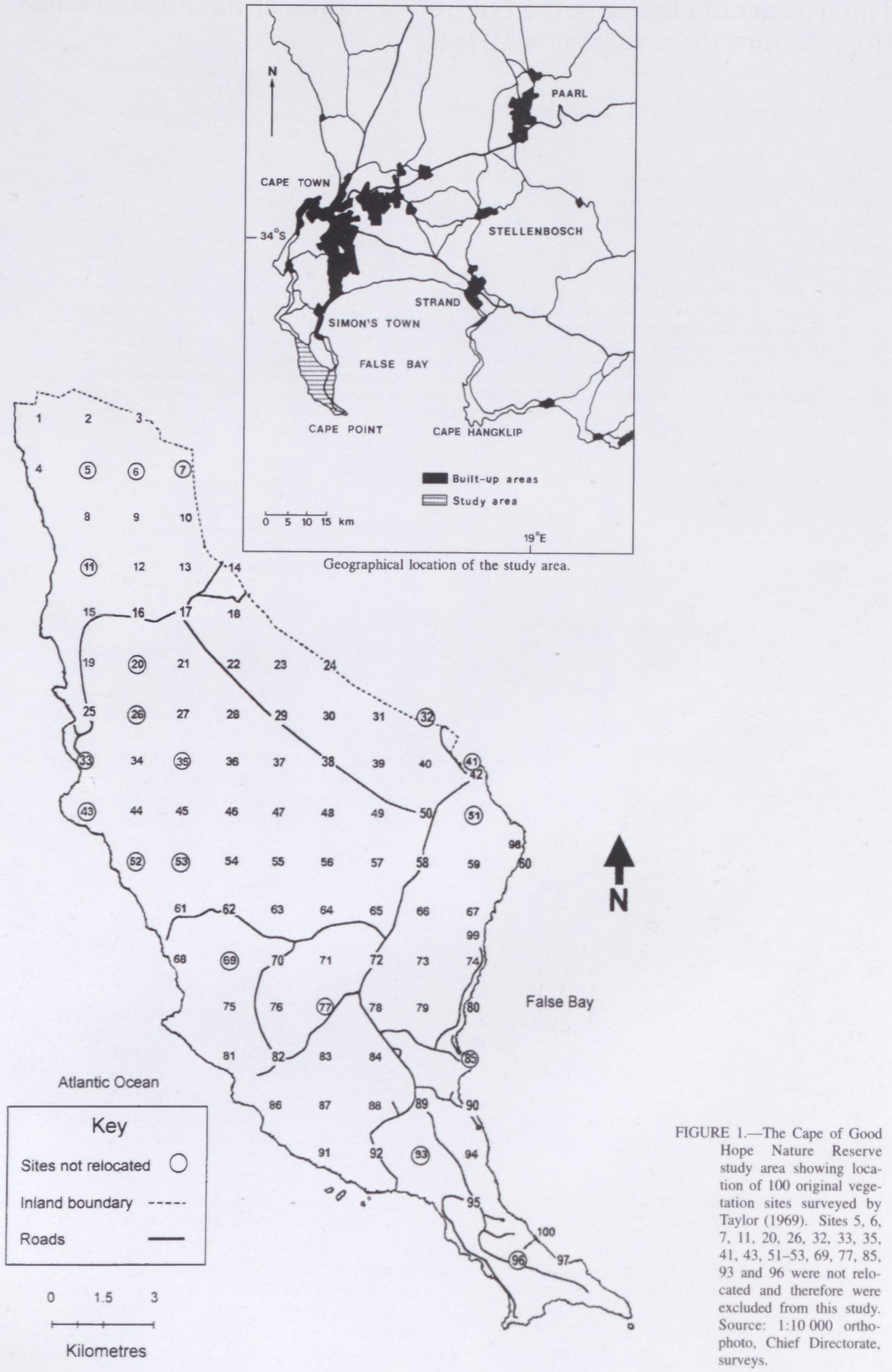


searched over the last few decades (Taylor 1978; Kruger 1984; Campbell 1985; Cowling \& Holmes 1992), no studies have explored the contribution of the temporal component to this complexity. Consequently little is known about the resilience of fynbos to change over time or how repeated disturbances influence patterns in vegetation distribution at the community and landscape scale. This study explored the resilience of fynbos vegetation in the Cape of Good Hope Nature Reserve (CGHNR) to 30 years of variable disturbance, both natural and managed. The study used mostly a descriptive approach to explore changes in the composition of permanent vegetation sites established in 1966. It attempted to invoke explanations for the observed change from historical fire and alien plant records by asking the following questions:

1. How much change has occurred in the vegetation of the CGHNR between 1966 and 1996 ?

2. How important was post-fire age as a determinant of species composition and diversity?

3. What effects have long fire-free intervals had on vegetation dynamics in upland and coastal fynbos?

4. What impact have unusually short and long fire frequencies had on vegetation composition?

5. What impact has high intensity fire following long fire-free intervals had on vegetation composition and structure?

6. What has been the dynamics of the common serotinous overstorey species Leucadendron laureolum. and what impact has it had on understorey species diversity?

7. How has the abundance and range of invasive alien plants changed over the last 30 years, and what effect have these changes had on the indigenous flora of the Reserve?

\section{STUDY AREA}

The area encompassed by the Cape of Good Hope Nature Reserve (CGHNR) was used for this study (Figure 1). A detailed description of the physical setting and historical background of the Reserve is documented in Taylor (1984a). The Reserve had certain attributes that made it suitable for this study: high species diversity and complexity: the existence of permanent monitoring sites; and detailed management records including fire histories (Appendix 1) for the period since the establishment of the sites. The vegetation of the CGHNR has been well documented and a comprehensive list of I 073 species compiled (Taylor 1969. 1983, 1984a, b; Fraser \& McMahon 1995; Fraser in press.). The vegefation communities were described by Taylor (1984b) who emphasized the variability within communities and suggested that historical effects relating to disturbance had influenced within-community species heterogeneity.

\section{METHODS}

Taylor (1969) established 100 permanently marked vegetation quadrats of $50 \mathrm{~m}^{2}(5 \times 10 \mathrm{~m})$ during $1965 / 66$ (Figure 1). These provided the baseline species dataset against which a contemporary species list could be compared. The management records of the Reserve provided detailed information on both fire history and alien vegetation from 1960 to the present. Eighty-one of the 100 quadrats were relocated using Taylor's original site markers that demarcated the southwestern corner of each quadrat (Figure 1). All species present in each quadrat were noted with the exception of annuals and seasonally apparent geophytes, both of which were not perennially identifiable. Much effort went into ensuring that sites were precisely relocated and that species were accurately identified. This was crucial for achieving the objectives of the study. The nomenclature of all species was corrected according to Arnold \& De Wet (1993). The original species lists of Taylor (1969) were used to assist with identification.

The number of individuals of each species in a site was counted (estimates were made when distinction between individuals was difficult, e.g. resprouting Restionaceae) and later converted to a five-category system that corresponds to a simplified form of Acocks's (1975) system of abundance symbols (Table 1). This was done in order to be compatible with Taylor's (1969) study that used Acocks's (1975) symbols for assessing abundance. Hugh Taylor assisted with initial field work and was satisfied that the methodology corresponded with that used in his initial survey.

The changes in floristic composition within sites over the thirty year interval between surveys was explored using the Sörenson's coefficient (Kent \& Coker 1992) in the form of the following equation:

$$
S=\frac{(2 \times c)}{(a+b)} \times 100
$$

where $S_{\mathrm{s}}$ is the Sörenson coefficient as a percentage; $a$ is the number of species present at a site in 1966; $b$ is the number of species present at the same site in 1996: and c is the number of species present at both sampling times.

This coefficient was used throughout the study to quantify temporal changes in species composition. These results, together with the two temporally separated species data sets and matched photographs were used to explore established hypotheses relating to determinants of vegetation dynamics and temporal change in fynbos. We do not attempt to provide a detailed analysis of any aspect of fynbos dynamics in this study. We use specific examples of sites which have undergone changes relating to recorded fire or alien plant impacts to emphasize the role of these factors in structuring contemporary vegetation patterns.

TABLE 1_-Abundance categories used in this study

\begin{tabular}{cll}
\hline Category used & $\begin{array}{c}\text { Condensed Acock's } \\
\text { category }\end{array}$ & $\begin{array}{c}\text { Number of } \\
\text { individuals on site }\end{array}$ \\
\hline 1 & Occasional & 1 to 4 \\
2 & Fairly frequent & 5 to 10 \\
3 & Frequent & 11 to 50 \\
4 & Common & 51 to $1(x)$ \\
5 & Abundant & $>10(x)$
\end{tabular}




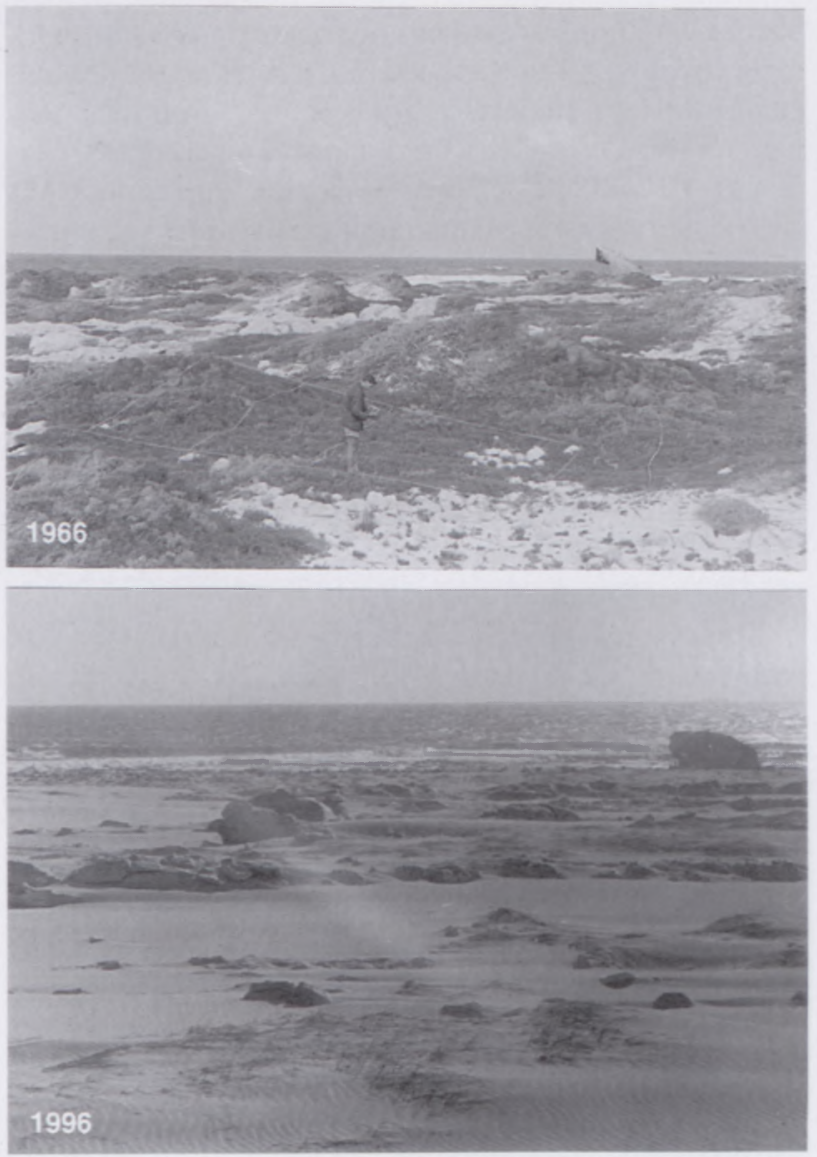

FIGURE 2.-Site 43 on western seaboard near Olifantsbos Point, was covered by asteraceous fynbos in 1966 . Over the last 30 years the entire area has been inundated by shifting dune sands, resulting in the local extinction of all species with the exception of the pioneer grass Ehrharta villosa. Wreck of Thomas T. Tucker is visible in background of both photographs.

\section{RESULTS AND DISCUSSION}

Nineteen of the original 100 sites were not included in this study due to problems with accurate re-location or through loss to infrastructure development. The 81 sites used in this study showed considerable variability in their floristic similarity between the two surveys (Appendix 1). The mean similarity for all sites was 61.8 $\pm 8.9 \%$, while the lowest value was $43.8 \%$ and the highest $84.3 \%$. The potential for extreme environmental change to alter the composition of a site was graphically illustrated by site 43 occurring near Olifants Point on the western seaboard of the Reserve. This site had to be excluded from the analyses as mobile dune sands have inundated it during the last 30 years (Figure 2).

\section{Fire effects}

\subsection{Post-fire succession}

Post-fire succession in fynbos is noted for a rapid initial establishment of all components of the community including those (fire ephemerals) that only appear in the first years after fire. Therefore, species diversity is greatest in the immediate post-fire environment and there is a marked decrease in species diversity as the cover of overstorey shrubs increases (Kruger 1987; Cowling \&
Pierce 1988; Cowling \& Gxaba 1990). The rate of decline in the successional sequence differs between areas with different environmental conditions. Growth in dry lowland fynbos sites is generally slower than in moister mountain fynbos and suppression of understorey species is predicted to start later, probably only after 30 years (Hoffman et al. 1987).

We explored the rate of post-fire succession for the Reserve as a whole as well as the role of post-fire age in influencing species diversity and composition. By including the data sets for both surveys it was possible to examine the effect of the full spectrum of vegetation ages on species diversity. Differences in the successional sequence between communities complicates the trend and therefore only the fire-prone mesic oligotrophic proteoid community was included. This community occurs on the well-drained rocky hills and is the dominant vegetation type of the Reserve (Privett 1998).

There was a significant negative relationship between vegetation age and species diversity within this community (Figure 3). The initial peak in species diversity was followed by a gradual decline over time. The significantly steeper negative slope of the 1966 data set $(-1.19 \pm$ 0.24 as against $-0.54 \pm 0.1 ; \mathrm{F}=5.97, \mathrm{df}=1, P<0.02$ ) resulted from the inclusion of a number of young sites ( $<4$ years post-fire) which had high species diversity. The mean number of perennial species recorded in 1966 was $38.2 \pm 17.4$ per site, the maximum was 79 and the minimum was six. In 1996 there were on average fewer species per site $(35.6 \pm 15.5)$. This suggests that there is a rapid decline from an initial post-fire peak and that the majority of post-fire ephemerals have seeded and died within four years after fire. Thereafter species are lost from the community at a slower rate.

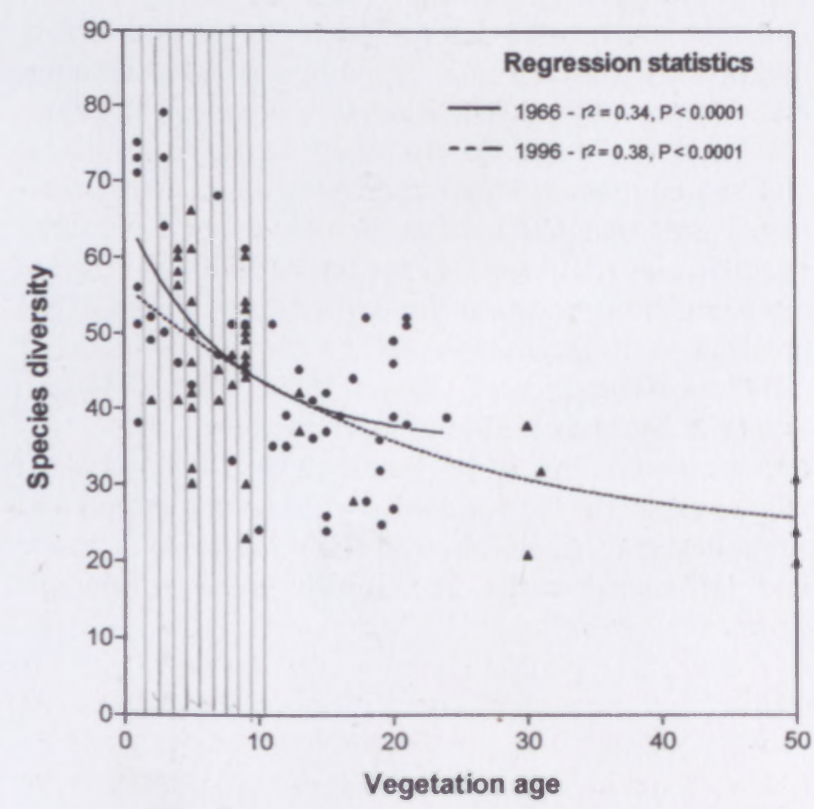

FIGURE 3.-Relationship between vegetation age and species diversity in $\mathbf{5 0}$ mesic oligotrophic proteoid sites at the two sampling times. Fitted curves are negative exponential, circles represent 1966 sites and triangles 1996 sites. 

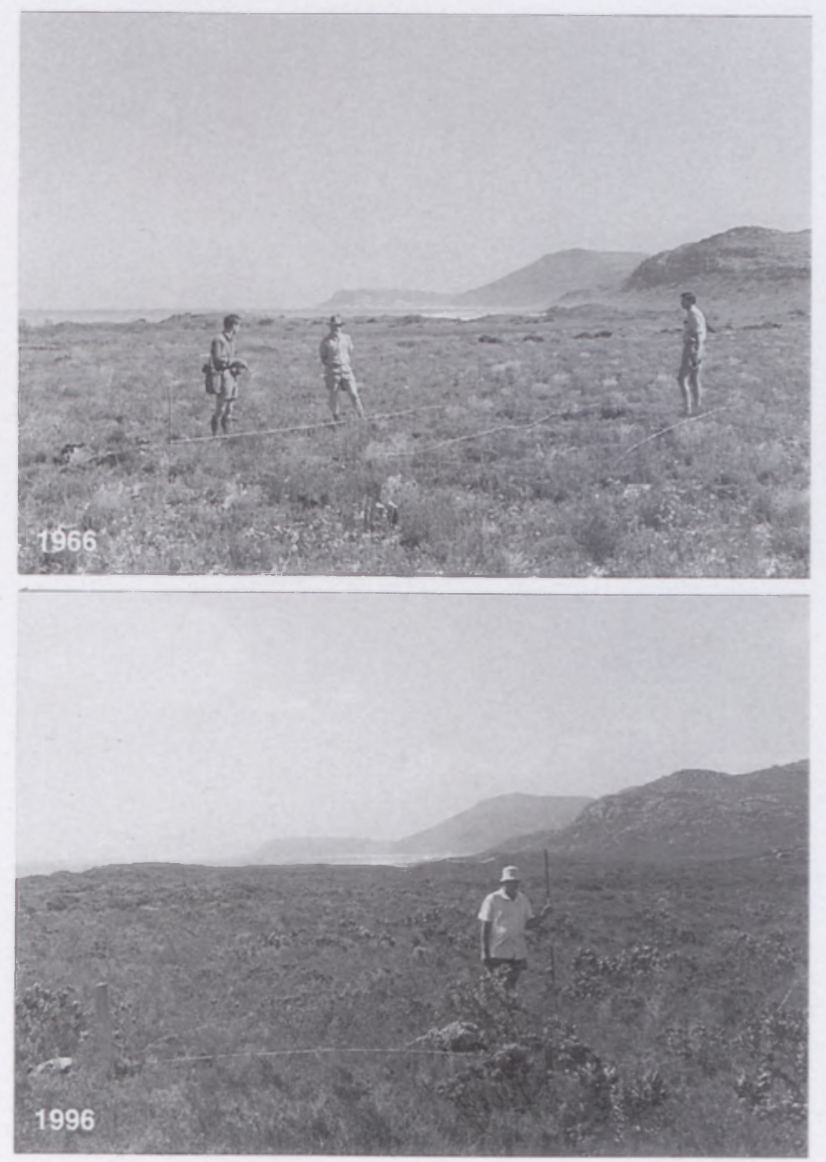

FIGURE 4.-Site 15 near Groot Rondevlei, has shown a marked decline in species diversity between surveys as a result of successional effects. The low, white flowering shrub in the 1966 photograph (three years post-fire) is the post-fire ephemeral Edmondia sesamoides which was not present in the older vegetation in 1996 (nine years post-fire). The 1966 vegetation is characterized by the visible dominance of the resprouting graminoid guild, whereas in the older 1996 vegetation, the nonsprouting shrubs, Leucadendron laureolum and Serruria villosa are dominant. Note the invasion between surveys of the Witsands dune field (headland in middle, background of photograph) by the invasive alien, Acacia cyclops.

\subsubsection{Early successional changes}

Figure 3 illustrates the initial decline in species diversity during the first four years following fire. One of the relocated sites (15) provided an opportunity for exploring the differences in vegetation composition between very young and slightly older vegetation (Figure 4 ). The impact of fire season and frequency on the site's vegetation between surveys should be negligible as the site was burnt twice in summer wildfires at intervals of twelve and then eleven years. In 1966 this site was only three years old and included 66 species, whereas in the nineyear-old vegetation in 1996 only 27 species were recorded. Despite only six years difference in the post-fire age at the two sampling times, successional effects have resulted in major compositional changes in this site between surveys $\left(S_{\mathrm{s}}=49.46 \%\right)$. Only four of the 27 species recorded in 1996 were new to this site suggesting that the compositional change which has occurred was as a direct result of losses due to successional effects. The 43 species lost include a number of fire ephemerals such as Aspalathus abietina, A. linguiloba, A. retroflexa, Roella ciliata, $R$. triflora, Selago spuria, Thesium cari- natum and T. acuminatum as well as the predominantly early successional species such as Edmondia sesamoides and Ursinia crithmifolia (Asteraceae).

The stage in the post-fire succession of fynbos vegetation influences the composition and diversity of communities. This has important implications for ecologists developing community-environment models and wherever possible successional effects should be controlled by only sampling in similar-aged stands.

\subsubsection{Successional changes after long fire-free intervals in upland fynbos}

Fynbos is a fire-prone vegetation whose component species have a variety of fire-regeneration traits. Fire is an important process for the regeneration of many species and in its absence these species senesce and eventually die (Bond 1980; Van Wilgen 1981). With long fire-free intervals species diversity declines but at the same time bird-dispersed species are introduced as perch sites develop (Manders \& Richardson 1992; Cowling et al. 1997). The late stages of fynbos succession are characterized by autogenic changes and follow the facilitation model of Connell \& Slayter (1977). Seeds of forest and thicket species are dispersed into shrublands, and seedlings sometimes establish in mature fynbos communities, especially in sheltered sites (Cowling et al. 1997). The slow-growing seedlings of thicket species are usually killed by fire before thicket patches have developed sufficiently to exclude fires. However, where fire-free intervals exceed approximately fifty years, dense thickets form which eventually coalesce into closed-canopy vegetation that excludes fire (Manders \& Richardson 1992; Richardson \& Van Wilgen 1985, Cowling et al. 1997). In drier lowland fynbos the rate at which species senesce and thicket develops presumably takes longer than for wet mountain fynbos (Hoffman et al. 1987; Privett 1998). Five of the sites enumerated in 1966 had not burnt once at the time of the second survey $(74,81$, 95,99 and 100). These provided an opportunity to determine the rate of senescence and thicket development in the relatively dry fynbos of the southern Cape Peninsula.

The mean of the Sörenson coefficient for these upland fynbos sites was $58.5 \pm 7 \%$; the lowest value was for site $95(46 \%)$ and the highest was for site $81(66.7 \%)$. The diversity of all sites, with the exception of site 99 , which remained constant, declined between surveys. Two of these sites have not burnt for more than fifty years and have similar habitat characteristics (74, Figure 5 and 81 , Figure 6). They are located on relatively steep slopes at approximately $90 \mathrm{~m}$ above sea level and adjacent to the coast. The one is situated on an east-facing slope above False Bay (74), while site 81 is located on a west-facing slope above the Atlantic Ocean. Site 74 is therefore exposed to the strong salt-laden southeasterly winds during the summer months, whereas site 81 is more protected from wind but still exposed to strong northwesterlies in winter.

Predictably, both sites were relatively species poor. However, neither had experienced significant thicket development (Figures 5, 6). Both sites had lost several 

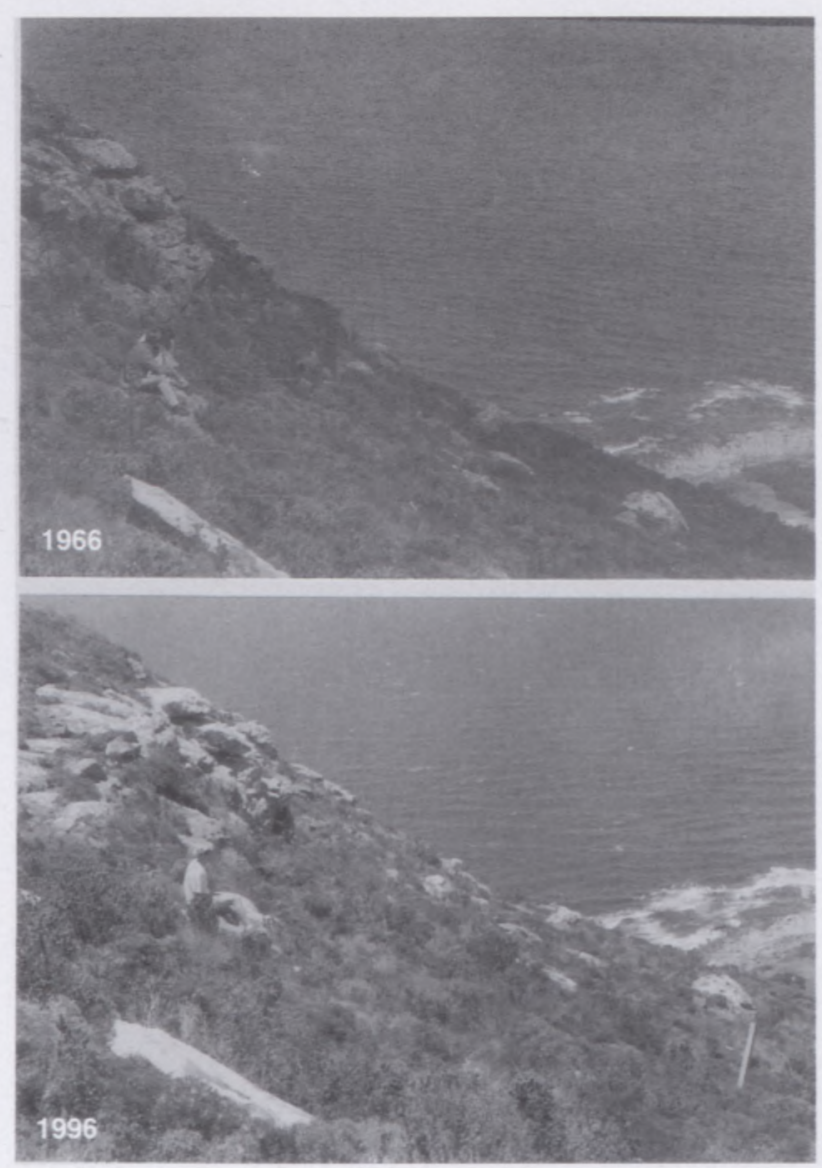

FIGURE 5.-Site 74, oligotrophic proteoid fynbos on the southern slopes of Paulsberg overlooking False Bay, is exposed to strong southeast winds during the dry summer months. This vegetation was at least 20 years old in 1966 and has not been burnt between surveys. There has been very little change in species composition or structure over the last 30 years. While there has been some senescence among both the sprouting and nonsprouting species, there has been no colonization by thicket species despite fifty years without fire.

species, most of which were shorter-lived non-sprouters such as Anthospermum aethiopicum, Chironia baccifera, Erica mammosa, Leucospermum conocarpodendron (a weak sprouter), Metalasia muricata, Struthiola ciliata and Serruria villosa. However, the species that had been lost from these sites also included some sprouting species such as Adenandra villosa, Corymbium africanum, Erica cerinthoides and Liparia parva. Therefore, a variety of species with different regeneration modes had a lifespan long enough to survive the initial twenty years without fire, but were unable to survive for fifty years.

Even within the Reserve, differences exist in the potential for, and rate of, thicket colonization. The habitat of site 81 appears to be more suitable for the development of thicket than that of site 74. The thicket species, Euclea racemosa, Myrsine africana, Olea capensis, Rhus lucida and $R$. laevigata were already present at this site in 1966, whereas site 74 supported no thicket species. The better early colonization of site 81 is probably a result of its taller structure, thereby providing more perch sites, and its peripheral location to a nearby thicket. Since the initial survey, neither site has demonstrated a notable increase in thicket species. The bird-dispersed Rhus lucida and Pterocelastrus tricuspidatus colonized sites 74 and 81 respectively. Erica tristis, a tree
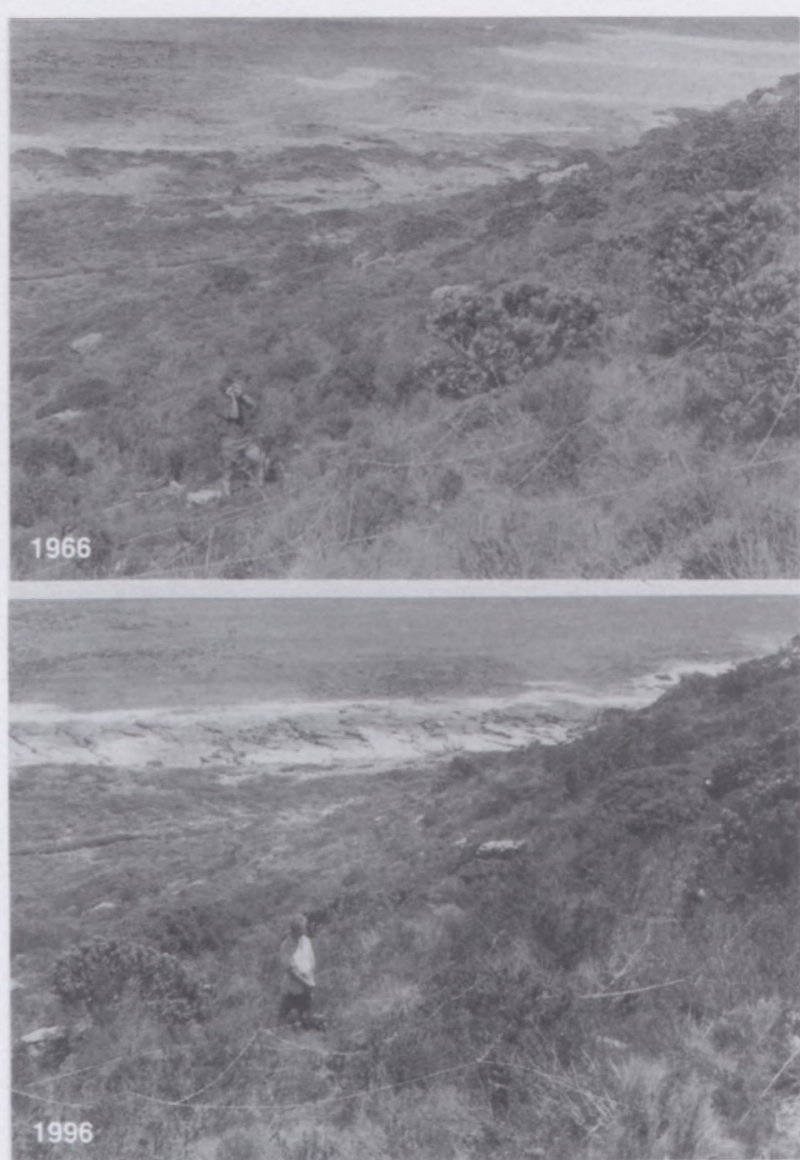

FIGURE 6.-Site 81, oligotrophic proteoid fynbos above large coastal thicket at Gifkommetiie, is situated on the upper slopes of a fireprotected amphitheatre above the Atlantic coast. The vegetation was at least 20 years old in 1966 and has not burnt between surveys. In 1966 the site contained some seedlings of thicket species. These have not developed into adult trees over the last 30 years. The vegetation has remained very stable with only the loss of a few non-sprouting species and the addition of some short-lived colonizers between surveys. Despite a fire-free period of \pm 50 years, and its close proximity to a well-established thicket, this site has not developed into a thicket. Some individuals of Leucospermum conocarpodendron are visible in both photographs suggesting that this species has a lifespan in excess of 50 years.

erica associated with fire-free sites, colonized site 81 The few other species, which have colonized the sites, are mostly small wind-dispersed shrubs and graminoids. There has been a small increase in the number of individuals of thicket species present at site 81 , but they have shown virtually no increase in relative dominance over the last 30 years. After 30 years Olea capensis is still only present as suppressed seedlings, whereas seven of the nine Euclea racemosa individuals are also seedlings or suppressed saplings.

The physical environment of the southern Cape Peninsula appears unsuitable for the rapid development of thicket or forest. Thicket colonization in this area is an extremely slow process, which, under favourable conditions appears to require fire-free intervals in the order of centuries rather than decades. Even under the long natural fire regimes of the past, the vegetation of the mountainous southern Reserve probably comprised an assemblage of longer-lived fynbos plants, rather than a thicket community. 

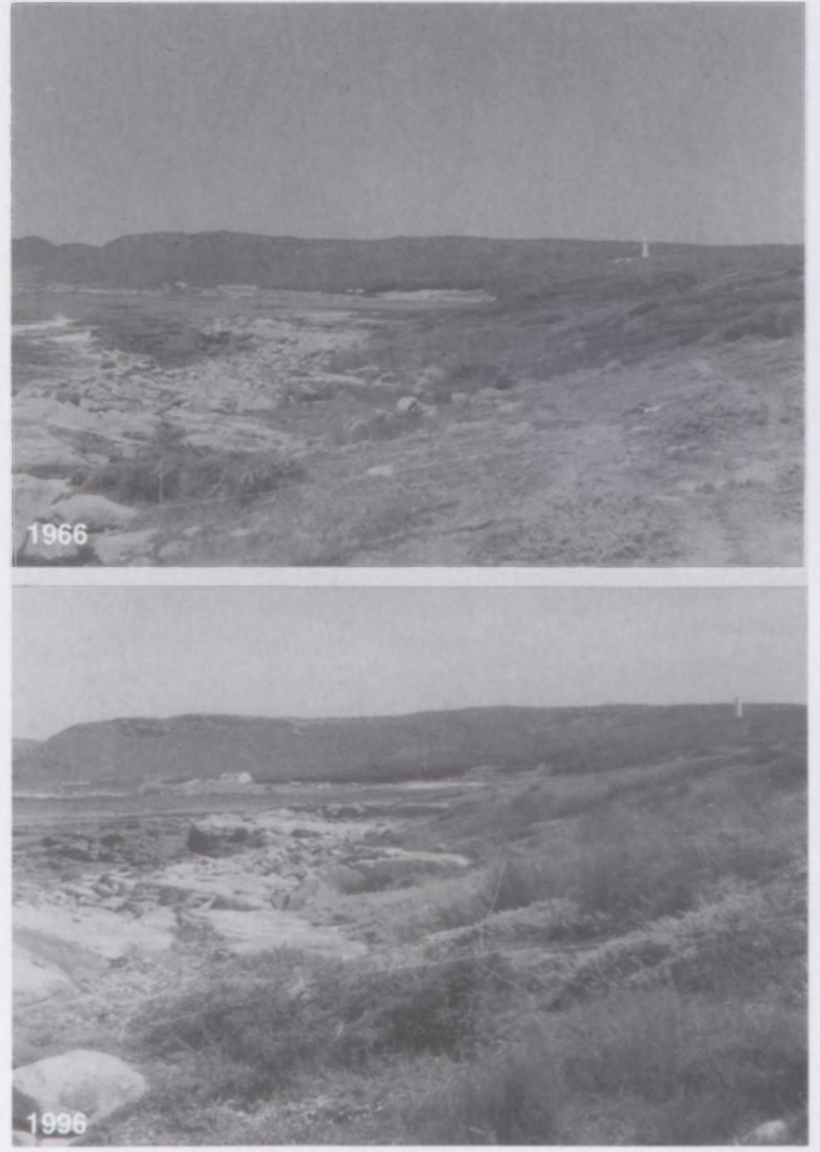

FIGURE 7.-Site 80, coastal scree asteraceous fynbos near Black Rocks on the False Bay coast, was already very old in 1966 and has not been burnt since. The species composition has remained stable between surveys. There has been an increase in the cover and biomass of Scirpus nudosus (graminoid in the middle of the site). This is most probably the result of an improvement in soil moisture since stands of Acacia cyclops were removed above the site between surveys. Evidence for the longevity of some shrubs is provided by the persistence of a single individual of the resprouting Asparagus capensis in the bottom left hand comer of both photographs. This individual is well over 30 years old.

1.1.3. Successional changes after long fire-free intervals in coastal fynbos

Unlike the upland fynbos, coastal asteraceous and coastal thicket communities are less frequently burnt owing to their location adjacent to the sea. It can therefore be hypothesized that species occurring in these communities are not fire adapted, and that they are more stable in the long-term absence of fire.

Taylor estimated the ages of sites 80 (Figure 7) and 90 (Figure 8 ) as very old in 1966 and neither have experienced fire between the two surveys. These two sites are quite different in their floristic composition. Both are situated adjacent to the False Bay coastline. However, site 80 is dwarf scrub on shallow, rocky and damp soils, while site 90 is a typical coastal dune thicket on deep well-drained calcareous sands. The Sörenson coefficients for these sites were $71.1 \%$ and $79.0 \%$ respectively. They were therefore amongst the most stable in this study. They showed no change in the relative proportion of growth form or regeneration mode between surveys. Numbers of species only decreased slightly between surveys. The most obvious change in site 80 was the large
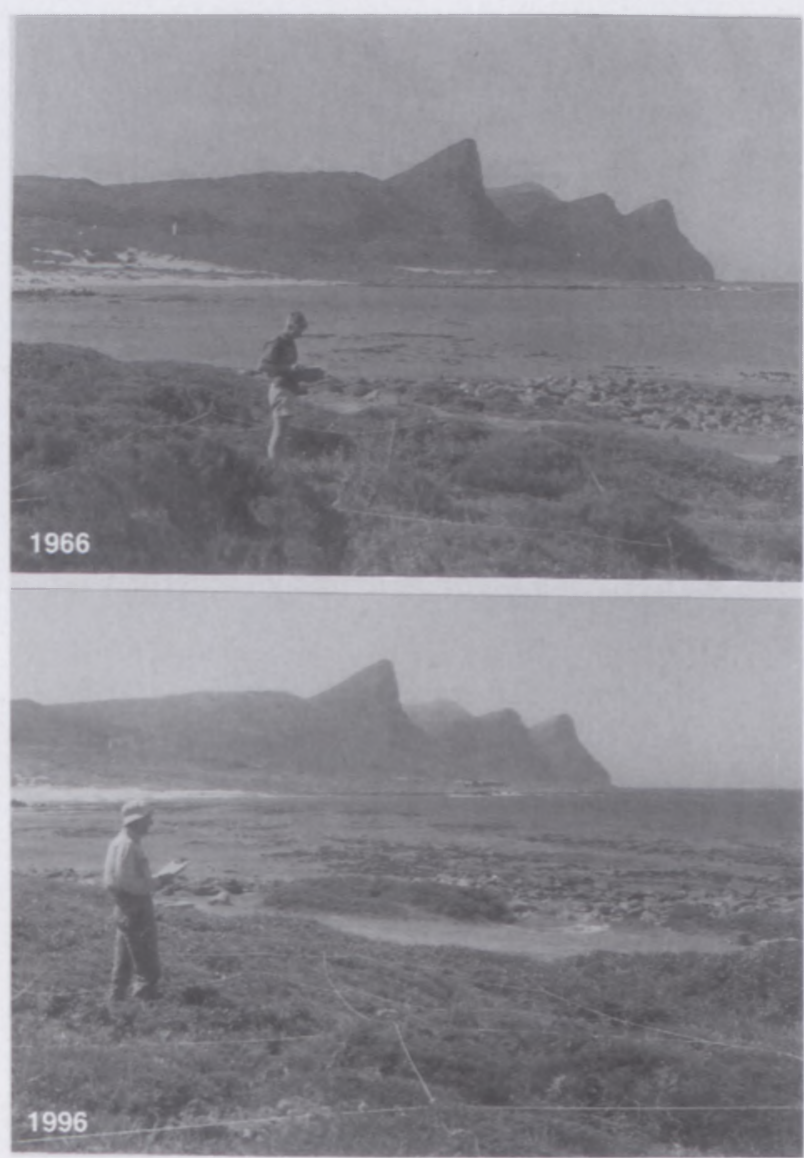

FIGURE 8.-Site 90, coastal dune thicket on the False Bay coast at Buffelsbaai. This vegetation type has remained very stable in composition over the last 30 years. It is dominated by the thicket species Sideroxylon inerme, Cassine peragua and Rhus species. All of these species are long-lived and, as a result, the community is stable in the absence of fire. The mountain peaks in the background are from left to right: Paulsberg. Die Boer and Judas Peak. The person in both photographs is Hugh Taylor, who initially established the permanent sites in 1966.

increase in the sedge Scirpus nudosus (Figure 7). This could be attributed to the eradication of stands of Acacia cyclops above this site, and the subsequent improvement in the hydrological regime. At site 90 there has been virtually no change in species composition and dominance. The coastal thicket species Sideroxylon inerme, Cassine peragua and Rhus species have remained dominant with approximately the same relative cover.

It can be concluded that the vegetation of the coastal communities, especially the dune thicket, is very stable in the absence of fire. These communities tend to be dominated by long-lived, slow-growing species that are able to persist for many decades (or centuries) in the absence of fire.

\subsection{Fire frequency}

Fires in fynbos occur with intervals of between four and 40 years (Le Maitre \& Midgley 1992). The natural fire frequency for fynbos in the Cederberg Mountain Range, some $200 \mathrm{~km}$ to the north, was estimated at between 11 and 15 years (Brown et al. 1991). Owing to its peninsular geography, the vegetation of the southern Cape Peninsula would probably have burnt less fre- 


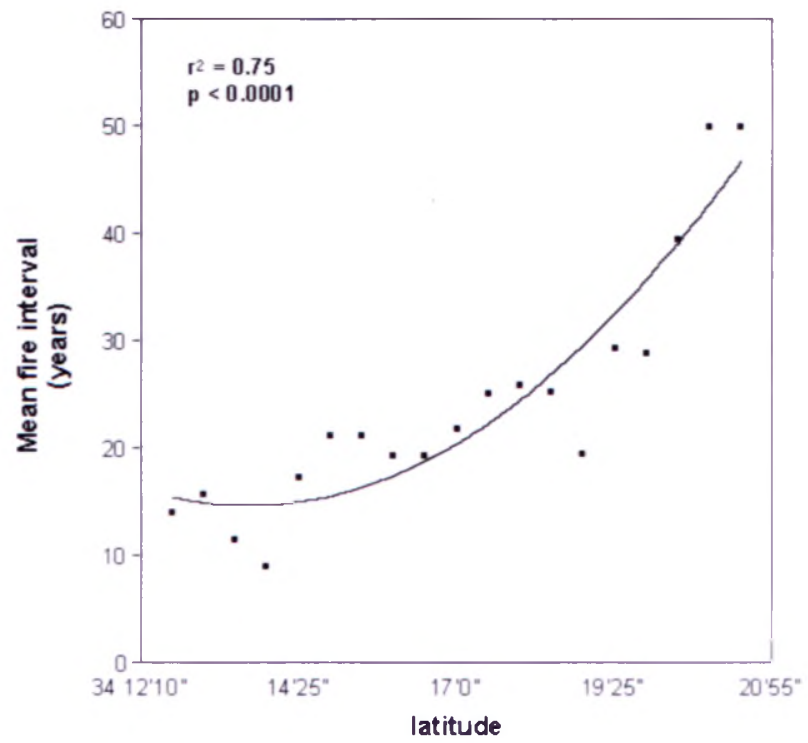

FIGURE 9.- The relationship between mean fire interval and latitude in the Cape of Good Hope Nature Reserve.

quently than landlocked areas further inland. An analysis of the last fifty years" fire records for the Reserve revealed an average fire interval of 23.2 years. This was calculated as the average of the frequencies for all sites from the fire prior to Taylor's survey and included prescribed burns. The pre-colonial fire interval was probably even longer. The area was inhabited by the Peninsular Khoikhoi who had little incentive to start fires as they subsisted on marine resources rather than livestock products (Elphick 1977).

There was a significant positive relationship between latitude in the Reserve and the mean fire interval (Figure 9). Sites in the southern areas of the reserve, where the Cape Peninsula narrows to less than a few kilometres. have had a longer average fire frequency than those in the northern areas. Fires at unusually short, or long intervals, can alter the species composition of fynbos (Van Wilgen 1981; Van Wilgen \& Forsyth 1992; Vlok 1996; Schwilk et al. 1997). Frequent burning can alter species composition by eliminating the large non-sprouting shrubs, especially Proteaceae, as they do not have sufficient time to reach maturity between fires (Van Wilgen \& Kruger 1981; Van Wilgen 1981). Fast maturing and sprouting species should be favoured by a short fire frequency (Vlok 1996). Increased competition from the sprouters also results in a decline in non-sprouters, and a decline in overall diversity of a site (Vlok 1996).

Where fire is excluded for more than \pm 30 years, senescence occurs in some species and seed stores become depleted. Poor regeneration and even local extinction may follow such long intervals between fires (Bond 1980). A further consequence of long intervals between fires is that fuel loads increase, resulting in higher fire intensities. These fires have been shown to increase seedling recruitment of myrmecochorous Proteaceae (Bond et al. 1990), as well as to cause higher mortality among certain resprouting species (Le Maitre 1986).

\subsubsection{Short intervals between fires}

Only one site in this study was burnt at a very short frequency (site 14) and could be used to infer the impacts of short fire intervals on the vegetation (no photograph available for 1966). Between 1970 and 1988 site 14 on the eastern boundary of the Reserve was burnt on a threeyear rotation as one of three tracer belts making up a boundary fire break. These fires were carried out under cool conditions during late autumn or winter. At the time of Taylor's original survey the vegetation on site 14 was only three years post-fire, whereas in 1996 it was eight years old.

This site has undergone considerable compositional change over the last 30 years. The Sörenson coefficient of only $55 \%$ was below average for the data set and only $48 \%$ of the original species were still present on the site. The changes in species composition were generally as predicted for short fire intervals. Species diversity decreased: there were 12 fewer species in the second survey. This decline was as a result of a combination of the impact of repeated short fire intervals and the later stage in the post-fire succession in the 1996 survey. Some of the locally extinct species are relatively slow-maturing non-sprouters and were probably lost as a direct consequence of the short fire intervals. These include Erica plukenetii, Psoralea imbricata and Leucadendron laureolum; the last-mentioned being common in the vegetation adjacent to the old fire break. Other species lost from this site such as Roella ciliatum, $R$. prostratum and Thesium spicatum, are early successional species, which under a normal fire regime are unlikely to be present in vegetation of eight years post-fire age. The changes were not restricted to the non-sprouters as only $54 \%$ of the original sprouting species were present in the second survey. It would appear that the short fire frequencies might have also been detrimental to some sprouting species. However, the relative dominance of sprouting species has increased between the surveys with species such as Hypodiscus aristatus and Chondropetalum nudum showing considerable increases in cover.

Evidence from this single site supports the findings of Vlok (1996) that short fire frequencies result in an increase in the coverage of sprouting species, and as a result, a decline in non-sprouters and in overall diversity. The most plausible explanation for this change is that short fire frequencies eliminate non-sprouting species (as was the case at this site) thereby reducing competition and favouring sprouters.

\subsubsection{Long intervals between fires}

Eighteen of the sites have experienced at least one long ( $>30$ year) fire interval since the fire prior to Taylor's survey and have not been invaded by alien vegetation. On average these sites showed a higher similarity in species composition between surveys $(65.2 \%)$ than the average for the complete data set. These sites were used to examine the effects of long intervals between fires on the numbers of individuals of serotinous and myrmecochorous Proteaceac. 
TABLE 2.-Comparison of response of serotinous and myrmecochorous Proteaceae from $18\left(5 \times 10 \mathrm{~m}^{2}\right)$ sites sampled in 1966 and 1996, which experienced a long interval ( $>30$ years) between fires in Cape of Good Hope Nature Reserve

\begin{tabular}{lcc}
\hline & \multicolumn{2}{c}{ No. sites } \\
& $\begin{array}{c}\text { Serotinous } \\
\text { spp. }\end{array}$ & $\begin{array}{c}\text { Myrme- } \\
\text { cochorous spp. }\end{array}$ \\
\hline Absent in both surveys & 6 & 12 \\
$\begin{array}{l}\text { Present with similar abundances } \\
\text { in both surveys }\end{array}$ & 7 & 1 \\
$\begin{array}{l}\text { Abundance increased in 1996 } \\
\text { Colonised between surveys }\end{array}$ & 1 & 2 \\
Abundance declined in 1996 & 0 & 4 \\
Locally extinct between surveys & 4 & 0 \\
\hline
\end{tabular}

The response of serotinous and myrmecochorous species to long fire intervals differed in the Reserve (Table 2). Serotinous non-sprouting Proteaceae such as Leucadendron coniferum, $L$. xanthoconus and the common $L$. laureolum showed a tendency to decline in sites that have experienced long fire-free intervals $(>30$ years). This supports the findings of Bond (1980) that fire in senescent fynbos results in smaller daughter populations or even local extinction of serotinous species. As predicted, myrmecochorous species showed an increase in abundance and even colonized some sites after high intensity fires. This supports the hypothesis that seedling recruitment in these species is strongly and positively related to local fire intensity (Bond et al. 1990). Adult mortality is, however, often high after these intense fires. A random survey of individuals of the myrmecochorous species Leucospermum conocarpodendron and Mimetes fimbrifolius in the vicinity of site 92 (Figure 10) showed that $97 \%(n=66)$ of the adult trees were killed in fortyfive year old vegetation during the 1991 summer wildfire.

Because of its sea-bound geography, the southern Peninsula experiences unusually long fire intervals. This has favoured species with unusual life histories such as the myrmecochorous tree proteoids, Leucospermum conocarpodendron and Mimetes fimbrifolius and the tree erica, Erica tristis. It would appear that the myrmecochorous tree Proteaceae are adapted to long fire-free intervals which facilitate high seedling regeneration and subsequent maturation after long-interval, intense fires. Although adult survival is much higher in low intensity fires, seedling recruitment is low and the species can be expected to decline following repeated short intervals between fires (Midgley et al. 1998).

There was no significant change in the proportion of sprouting versus non-sprouting species recorded at the two sample times $\left(\chi^{2}=2.8 \times 10^{-6}, P=0.99 \mathrm{NS}\right)$, nor the number of occurrences of sprouting versus non-sprouting species $\left(\chi^{2}=0.37,1\right.$ d.f., $P=0.53$ NS). This suggests that long fire-free intervals have not differentially favoured either regeneration strategies in the Reserve.

It can be concluded that high intensity fires after long ( $>30$ year) intervals have only minor effects on species composition but may result in a decline of serotinous, and an increase in myrmecochorous Proteaceae. The frequency of occurrence and average abundance of $L$. conocarpodendron and $M$. fimbrifolius for all sites in the
Reserve has remained constant between surveys (frequency; 1966, 11 sites, 1996, 10 sites, mean abundance; $1966,1.8,1996,1.9)$.

\section{Dynamics of serotinous Proteaceae}

The species data sets collected for this study provide an opportunity to explore the long-term (30 year) spatial and temporal dynamics of Leucadendron laureolum, a common serotinous species in the Reserve. We attempt to invoke exogenous explanations for its population fluctuations in terms of fire regime over the past 30 years. Serotinous Proteaceae are well known for their tendency for density fluctuations after fire. A variety of hypotheses have been proposed to explain these fluctuations (see Midgley 1989 for a review).

Leucadendron laureolum is very widely distributed in the Reserve and its densities are known to fluctuate over time (Le Maitre 1988; Cowling \& Gxaba 1990). This species is a habitat generalist (Williams 1972) which Taylor (1969) described as a 'weedy' species capable of forming dense stands in most of the fynbos communities
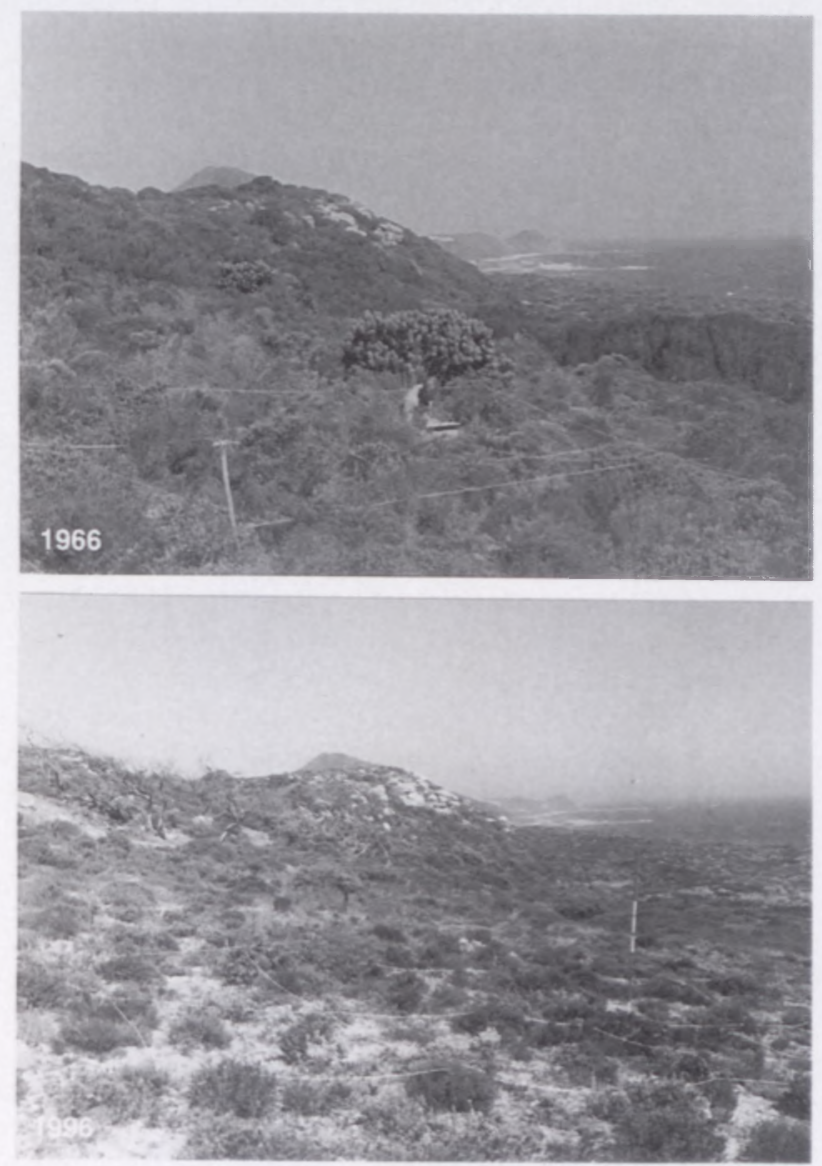

FIGURE 10.- Site 92, oligotrophic proteoid fynbos near Platboom: vegetation was 45 years old when it bumt in an intense summer fire in 1991. The species turnover between sampling times was $50 \%$. A large proportion of this change was as a result of the colonization of post-fire (asteraceous) species in 1996. The intense fire resulted in high mortality of Leucospermum conocarpodendron (tall proteoid bush in the middle of the 1966 photograph), but seedling recruitment of this species was high in the area. The thicket of Acacia cyclops in the background in 1966 was destroyed by the 1991 fire and the post-fire seedling cohort removed by clearing teams. 
TABLE 3.-Comparison of range and abundance of serotinous proteoid species, Leucadendron laureolum for $81(5 \times 10 \mathrm{~m})$ sites surveyed in 1966 and 1996 in Cape of Good Hope Nature Reserve. Sites colonized: species absent in 1966 and present in 1996. Sites extinct: species present in 1966 and absent in 1996

\begin{tabular}{lcc}
\hline & 1966 & 1996 \\
\hline No. sites occupied & 36 & 37 \\
Mean abundance at all sites & 2.91 & 2.92 \\
Sum of abundance at all sites & 72 & 74 \\
No. sites colonized & - & 11 \\
No. sites extinct & - & 10 \\
\hline
\end{tabular}

on sandstone-derived soils of the southern Cape Peninsula. A comparison of the distribution and density of $L$. laureolum in 1966 and 1996 showed that at the landscape scale this species has remained remarkably constant over the last 30 years (Table 3 ).

However, at the scale of the $50 \mathrm{~m}^{2}$ site most populations have fluctuated considerably over this time. While the number of sites occupied and overall abundance has remained constant, the species has undergone colonization and extinction at many sites (Table 3). L. laureolum has become extinct on nearly $30 \%$ of the sites occupied in 1966, whereas it has colonized a similar number of new sites in the same period. Furthermore, its abundance has remained constant at only nine out of the 26 sites in which it was recorded in both surveys.

\subsection{Causes of decline of serotinous Proteaceae (Figure 11)}

Fire season influences the regeneration of serotinous Proteaceae. Autumn fires favour regeneration of serotinous species, while winter and spring fires result in poor regeneration (Le Maitre 1988). Of the 15 sites at which L. laureolum either declined or went extinct, $40 \%$ were burnt at least once in winter. The winter fire was the last in the fire sequence at all except one of these sites. Short fire intervals $(<4$ years) were probably responsible for local extinction at a further two sites (14 and 48). Senescence after long fire-free intervals may also have contributed to the decline of this species at some sites. However, seven sites only experienced summer and/or autumn fires. Therefore nearly $50 \%$ of the sites at which $L$. laureolum declined were exposed to fires during theoretically favourable seasons. The decline in species at these sites could not be explained by fire regime and was more likely related to dispersal and/or competitive effects. Three of these sites had moderately dense stands (2 000 to 10000 stems per hectare) of $L$. laureolum present on them in 1966. Population declines at these densities could therefore have resulted from high levels of intraspecific competition. Cowling \& Gxaba (1990) suggested that the most plausible explanation for the shifting abundance of $L$. laureolum is the dispersal of its small, winged seeds by persistently strong southeasterly winds in the summer months after fire. Recent research into the desiccation tolerance of newly emerged Proteaceae seedlings demonstrated that $L$. laureolum had only moderate resistance to post-emergence desiccation (Mustart \& Cowling unpublished data). It would appear that for at
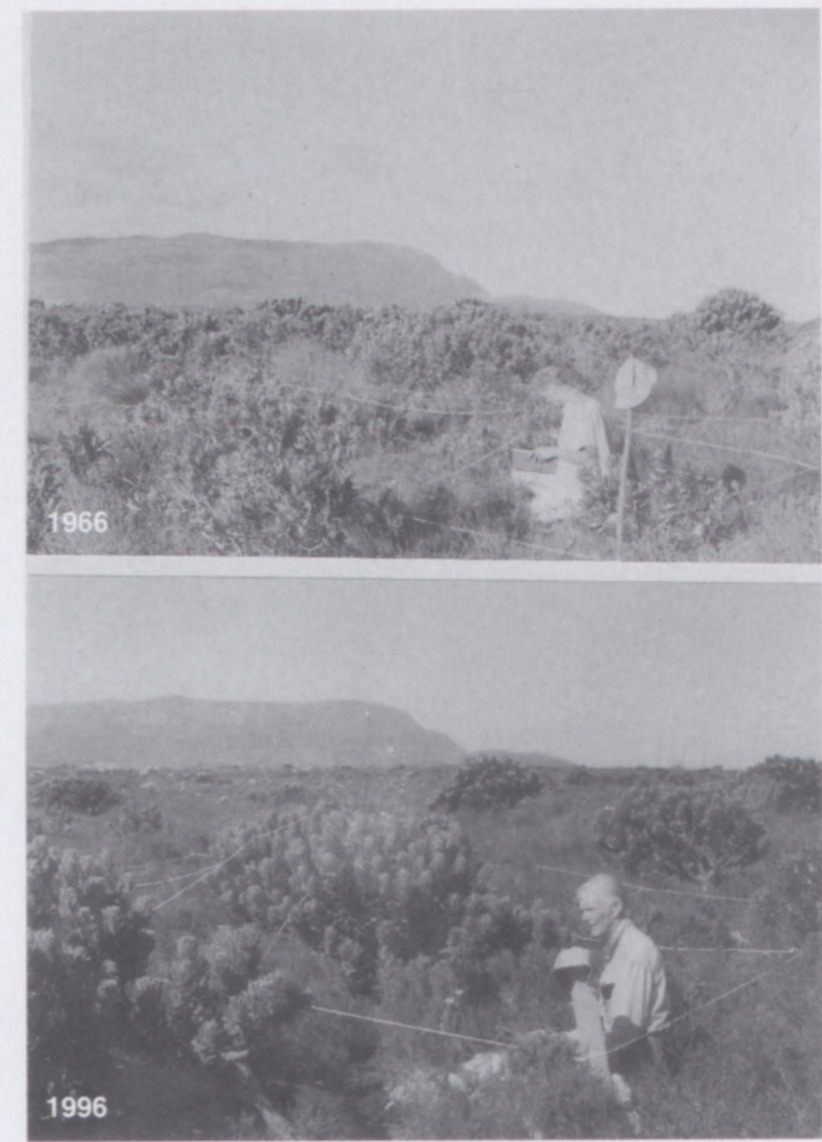

FIGURE 11.-Site 62, oligotrophic proteoid fynbos on the sandstone hill above Brightwater. The 1966 photograph shows Leucadendron laureolum as a common overstorey species at this site. It was burnt in a natural autumn fire in 1979 and a prescribed winter burn in 1988. The combined effects of these two fires resulted in the local extinction of this species from site 62 . It would appear from the photographs that the autumn fires have favoured the survival of the fire-tolerant adult Leucospermum conocarpodendron's (large proteoid bushes in 1996 photograph) at this site.

least four sites in this study, climatic events were the most likely explanation for population declines.

\subsection{Causes of increase of serotinous Proteaceae (Figures} $12,13)$

All sites, which have been colonized or shown an increase in cover, have experienced at least one autumn or summer fire ( 24 sites). Sixty seven percent of these were burnt exclusively in summer fires and only one had a winter fire as its last burn. Season of burn, therefore, appears to be an important determinant of post-fire population increases in $L$. laureolum: both summer and autumn fires favour increases in density. Nine of the eleven sites colonized were burnt exclusively in summer, while the remaining two were last burnt in an autumn fire. Colonization relies on effective dispersal of seeds into uninhabited sites. The high proportion of sites colonized following summer fires is most likely the result of dispersal of seeds into new sites by the strong SE winds during the summer months. Prescribed burns tend to be undertaken during the relatively windless autumn months resulting in less wind dispersal of seeds. Rapid germination following winter rains also results in the lower mobility of the species following autumn or winter burns. 

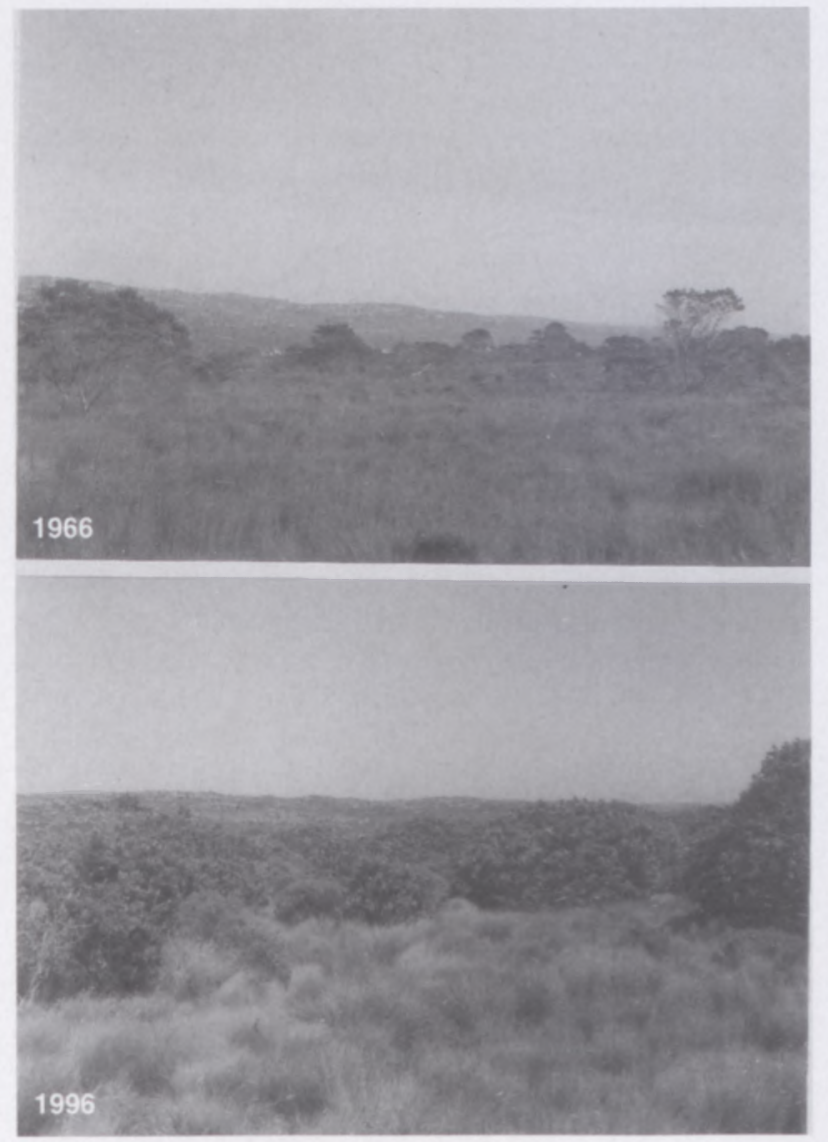

FIGURE 12.-Site 29, an unusual form of wet restioid fynbos on the Smitswinkel Flats which Taylor (1984b) described as "a distinctive woodland-like variety of seepage scrub with scattered Psoralea pinnata above a dense layer of grasses and Restionaceae'. This site has undergone considerable changes over the last 30 years (only $56 \%$ similarity). While the composition of the graminoid field layer has remained similar, a dense cover of Leucadendron laureoluin has replaced the scattered overstorey of $P$. pinnata.

2.3. The impact of $\mathrm{L}$. laureolum overstorey on under storey species diversity

The highly mobile nature of this species poses questions as to what effect dense stands have on understorey species composition. The majority of work on the impact of proteoid overstories has shown reductions in local richness of understorey species under dense stands (Campbell \& Van der Meulen 1980; Esler \& Cowling 1990; Cowling \& Gxaba 1990). Cowling \& Gxaba (1990) found that stands with sparse overstories of $L$. laureolum in the reserve had double the number of understorey species per square metre than dense stands. However, Vlok (1996) showed that high densities ( $>3000$ plants per hectare) of overstorey proteoids before a fire, enriched the local diversity levels of understorey species after a fire. Vlok (1996) noted that the spatial scale at which local diversity was measured affected the results of these studies. We used sites, which have undergone changes in the density of their proteoid overstorey to explore the consequence of these changes on understorey community composition.

A linear regression model was used to explore the relationship between changes in the abundance of $L$. laureolum between surveys and the corresponding changes in
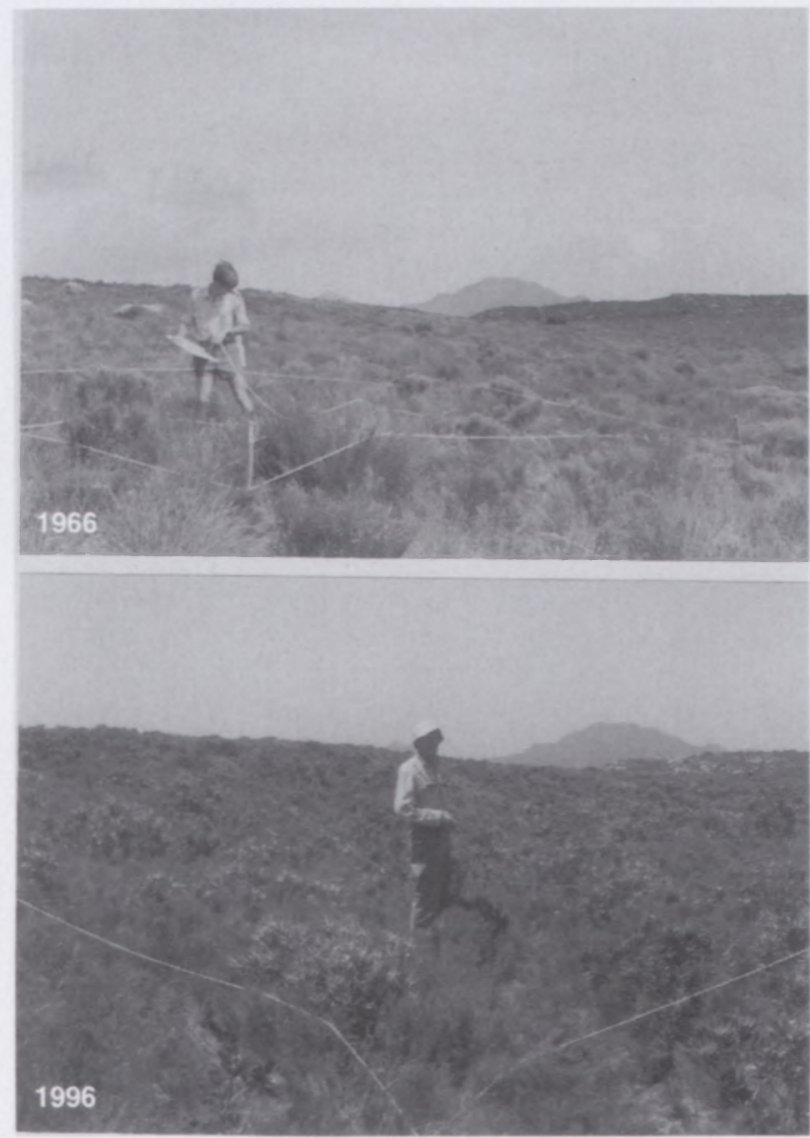

FIGURE 13.--Site 73, oligotrophic proteoid fynbos near Kanonkop. These matched photographs demonstrate the highly mobile nature of the non-sprouting serotinous species, Leucadendron laureolum. This species only recruits after fire. In the 1966 survey this species was not recorded in the vicinity of site 73 Between surveys the site burnt twice, the second time in 1983 was during the favourable autumn months. As a result in 1996 , the species was common throughout the area. Changes such as this, which result in compositional shifts in understorey species, were common at many sites between surveys.

species diversity. Both changes in abundance and in diversity were calculated by subtracting the values for 1996 from those of 1966. As succession can influence diversity, only sites with vegetation age $>4$ and $<20$ years at both sampling times were included in the analysis.

There was no significant relationship between changes in overstorey cover and changes in species diversity in this study (Figure 14). The 50\% reduction in diversity recorded by Cowling \& Gxaba (1990) was in small quadrats of $1 \mathrm{~m}^{2}$. This study utilized much larger quadrats $\left(50 \mathrm{~m}^{2}\right)$ thus allowing for greater heterogeneity and patchiness in the overstorey and consequently better survival opportunities for a range of understorey shrubs. The lack of pattern in this study could be the result of there being insufficient sites with high densities of $L$. laureolum. The increase in understorey diversity recorded by Vlok (1996) was under stands with densities of greater than 3000 stems. ha $^{-1}$. It would appear that cumpetition from overstorey proteoids only becomes important at very high densities (>3000 stems.ha ${ }^{-1}$ ). Light to moderate densities of proteoid overstorey do not significantly impact species diversity at the community scale.

The timespan of this study provides an indication that over the medium term, low to medium densities of over- 


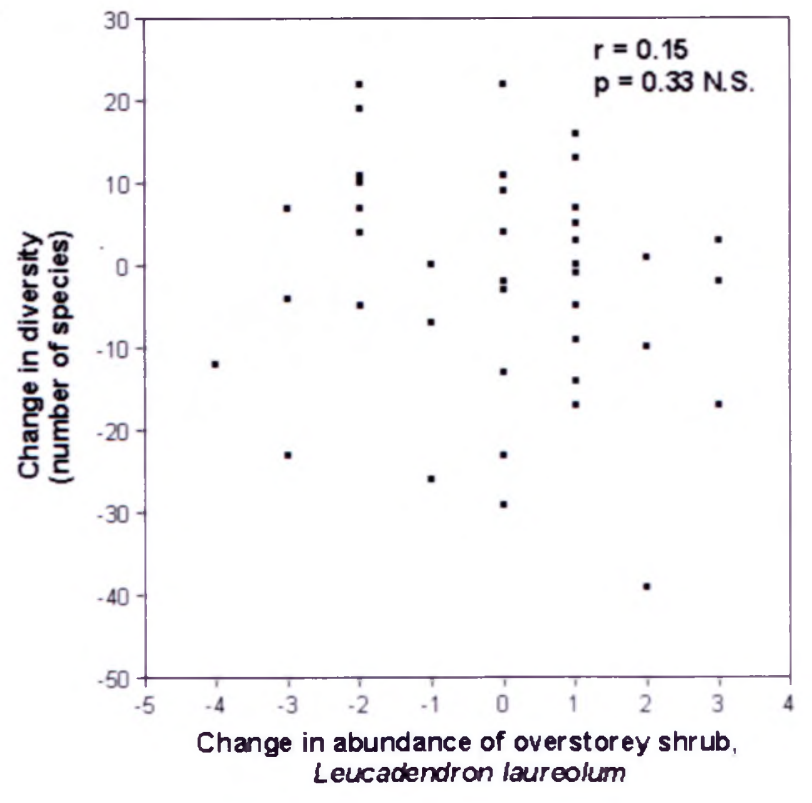

FIGURE 14.-The relationship between fluctuations in the density of L. laureolum over the last 30 years, and changes in species diversity. The abundance values can be converted to approximate densities per hectare as follows: $1=1-1000$ stems.ha ${ }^{-1}$; $2=1000-2000$ stems.ha ${ }^{-1} ; 3=2000-10000$ stems.ha $^{-1}$.

storey proteoid shrubs have little effect on the diversity of understorey species. Populations of overstorey proteoids demonstrated high mobility at the site level, yet remained remarkably constant at the landscape scale over time and appear to only influence understorey diversity at high densities.

\section{Alien plants}

Much of the fynbos biome has been impacted by dense stands of alien vegetation (Macdonald \& Richardson 1986; Richardson et al. 1992). The establishment of an overstorey of alien trees and shrubs markedly reduces the richness of fynbos communities (Richardson \& Van Wilgen 1985; Richardson et al. 1989; Holmes \& Cowling 1997). The rate of fynbos recovery following the removal of alien thickets declines with increasing period of invasion (Holmes \& Cowling 1997). The CGHNR has a long history of invasion by alien trees (Taylor \& Macdonald 1985; Taylor et al. 1985; Macdonald et al. 1989). Intensive mechanical control measures, involving initial felling of stands and subsequent follow-up on a 2-year rotation have been under- taken in the Reserve since 1981. These measures have probably been the most intensive continual clearing operation undertaken anywhere in the world. As the density of alien plants on each site was recorded at both sampling times, we were able to determine changes in density of alien plants across the Reserve as well as to explore the impacts of invasion on the indigenous vegetation.

\subsection{A comparison of the alien threat in 1966 and 1996}

The effectiveness of the Reserve's alien control programme was evident from the low occurrence and densities of alien plants in all except one site in the second survey (Table 4). In 1966 eight of the 81 sites contained alien plants, whereas in 1996 only five sites were infested. In addition there were a further four sites $(4,25,90$ and 92) which showed evidence of having been invaded by alien trees after the 1966 survey and that have subsequently been cleared prior to the second survey in 1996 Acacia cyclops is the only species still posing a major threat to the indigenous flora of the Reserve and is now concentrated on the steep slopes in the extreme southwest. This area has been included in future alien eradication planning. The only site that included a dense cover of alien plants was site 97 , which is located in this area of the Reserve. Outside of this area, alien plants were only encountered as scattered juveniles. The CGHNR eradication programme uses a system of covering the entire Reserve every two years to ensure that these seedlings will not mature. Pinus pinaster and Acacia saligna, which were both abundant at the time of the first survey, have been brought almost completely under control, with only occasional juveniles recorded in 1996

The alien eradication programme in the CGHNR has been effective at considerably reducing the threat of alien plants on the indigenous flora of the Reserve.

\subsection{Impact of aliens on indigenous vegetation}

\subsubsection{Sites invaded between surveys and subsequently cleared}

The two sites (25 and 95) which were densely invaded by alien trees in the period between surveys and subsequently cleared have regained less than $50 \%$ of their original species since clearing (mean Sörenson's coefficient of $45.28 \pm 2.1$ ). Sites $4.18,90$ and 92 were only moderately infested between surveys and have shown

TABLE 4.-Record of alien species in the $50 \mathrm{~m}^{2}$ sites in 1966 and 1996

\begin{tabular}{rlrl}
\hline Sites impacted by woody aliens in 1966 & Sites impacted by wordy aliens in 1996 \\
\hline Site & Density and species & Site & Density and species \\
16 & Occasional Pinus pinaster seedlings & 3 & Occasional Acacia saligna seedlings \\
18 & Occasional $P$. pinaster seedlings & 18 & Occasional Pinus pinaster seedlings \\
& Moderate Acacia saligna adult and seedlings & 95 & Occasional Acacia cyclops seedlings \\
24 & Occasional A. saligna adults & 97 & Closed A. cyclops thicket \\
68 & Occasional A. cyclops seedlings & 100 & Occasional A. cyclops adults \\
80 & Occasional A. cyclops seedlings & & \\
89 & Moderate A. cyclops adults & & \\
95 & Occasional A. cyclops adults & & \\
100 & Moderate A. cyclops adults and seedlings & & \\
\hline
\end{tabular}



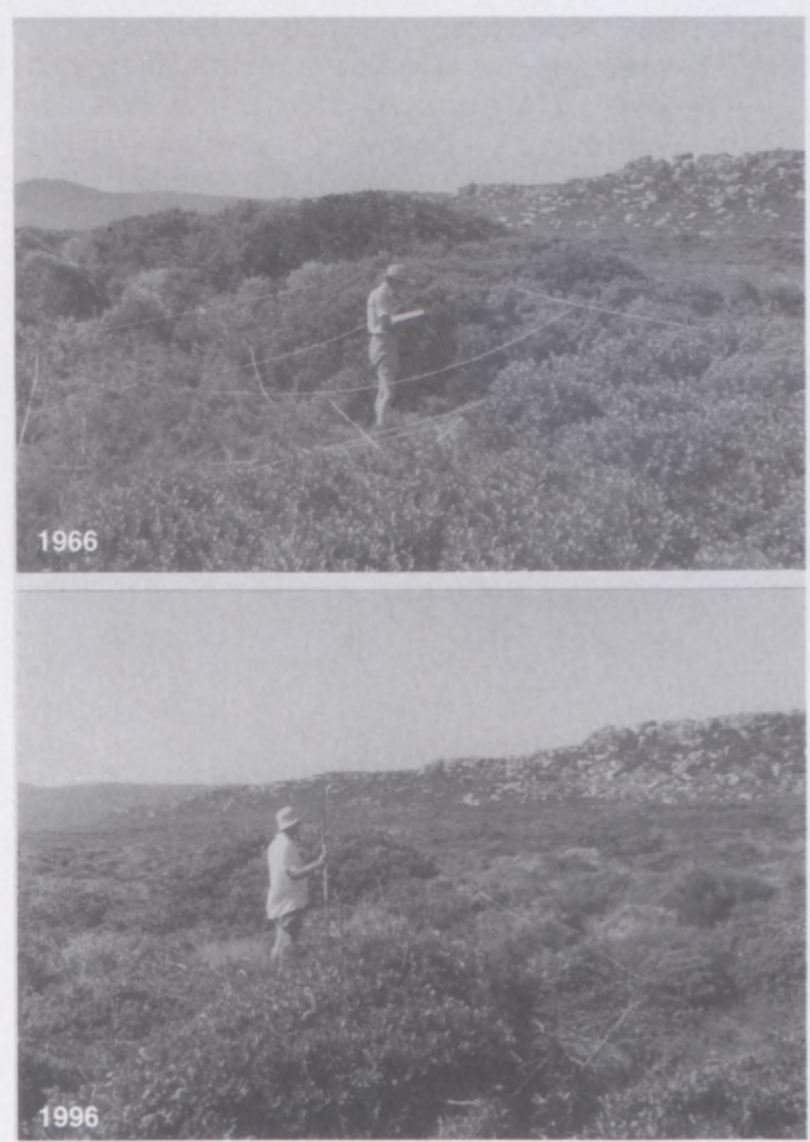

FIGURE 15.-Site 25, coastal dune thicket within $20 \mathrm{~m}$ of the Atlantic coastline at Olifantsbos Bay. In 1966 the site was characterized by a well-developed thicket. $A$. cyclops subsequently invaded the site. These trees were removed in 1986 and the natural vegetation has since started to recover. The sprouting guild is recovering well, while most of the non-sprouting species present in 1966 have been lost and have been replaced by shortlived post-disturbance species.

better recovery since clearing (mean Sörenson's coefficient of $58.66 \pm 13.6$ ). Site 25 provided an opportunity to explore the impacts of dense alien invasion on coastal dune vegetation (Figure 15).

This site is situated on coastal dunes within $20 \mathrm{~m}$ of the Atlantic coastline. In 1966 the vegetation was a dense coastal dune thicket of at least 30 years post-fire age. It was dominated by the thicket species Euclea racemosa, Rhus laevigata and $R$. glauca with a lower abundance of Pterocelastrus tricuspidatus and Cassine peragua. The graminoids Ficinia ramosissima and Ischyrolepis eleocharis dominated the ground layer. At that time there were no alien plants on the site but moderate densities of Acacia cyclops within a $200 \mathrm{~m}$ radius (Taylor 1969). The site was invaded by this species during the following twenty years, becoming densely infested before clearing in 1986 (CGHNR, unpublished records).

Seven of the 14 species present in 1966 still occupied the site in 1996. Of these, only Helichrysum dasyanthum was a non-sprouter. The typical coastal non-sprouters present in the initial survey such as Passerina paleacea, Coleonema album and Metalasia muricata had become locally extinct. Clearing of the alien trees has created gaps which have permitted colonization by a group of weedy, post-disturbance non-sprouting species including
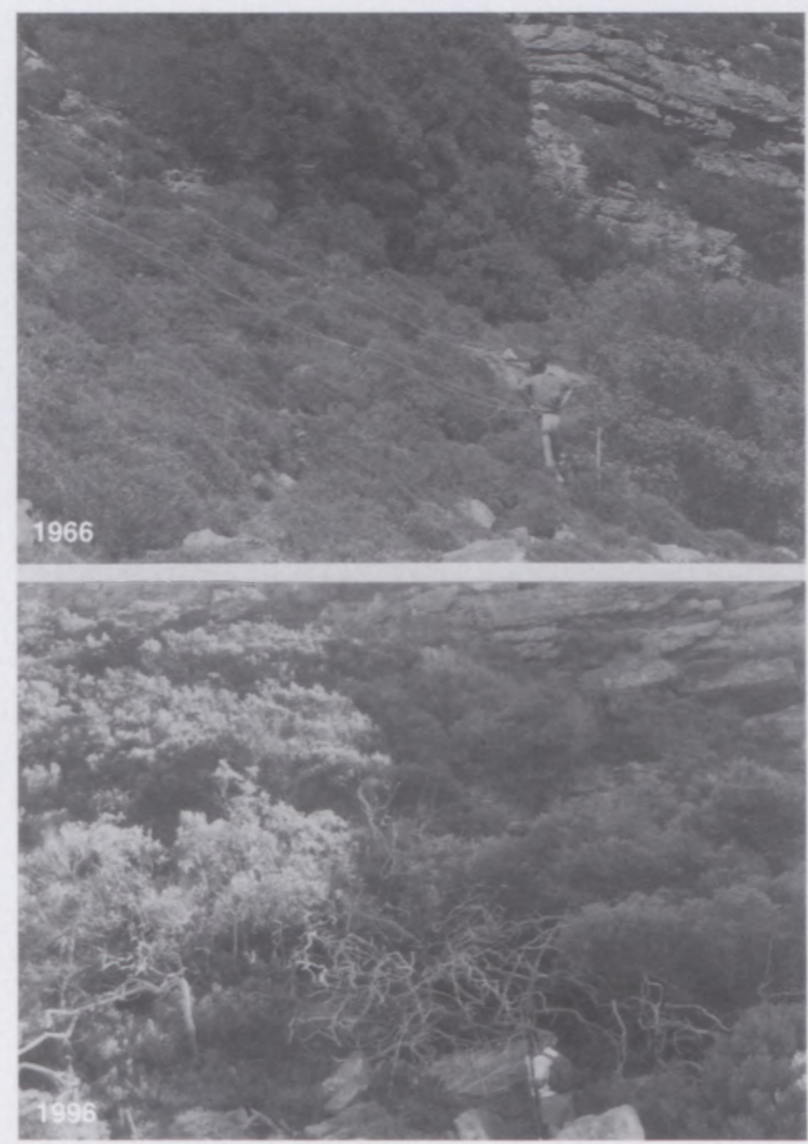

FIGURE 16.- Site 97, coastal scree asteraceous fynbos at Platbank on the False Bay coast near Cape Point. In 1966 the alien thicket was outside of the site (dark trees in the top of the photograph). Note the indigenous thicket of Tanchonanthus camphoratus in the bottom right hand comer (lighter trees). The site was invaded by 1973, and by 1996 Acacia cyclops covered the entire area. The result is that the cover of indigenous species has declined dramatically and most of the species have been eliminated (e.g. the skeletons of $T$. camphoratus are evident in the foreground of the 1996 photograph).

Cineraria geifolia, Senecio purpureus and Cullumia squarrosa as well as the sprouting pioneer graminoids Ehrharta villosa, Stenotaphrum secundatum and Pentaschistis pallida. None of these species were present in the 1966 thicket and, consequently, diversity on this site has temporarily increased as a result of clearing tree invaders. The six sprouting species that have persisted on the site included $E$. racemosa, $R$. laevigata and $R$. glau$c a$. These species were again dominating the site in 1996. The less abundant thicket species have all been lost as a consequence of invasion.

The invasion of this site by dense stands of $A$. cyclops had a major impact on the natural vegetation, especially non-sprouting species. The indigenous species are, however, recovering well since the aliens were eradicated.

\subsubsection{The impact of existing stands of alien plants}

Only one of the sites in this study has received no attention from clearing teams since the 1966 survey. Site 97 is situated below steep cliffs on the False Bay coast, close to Cape Point (Figure 16). In 1966 it contained only seven species, being dominated by a few low shrubs and succulent species of the family Aizoaceae. There 
were no aliens on site, but by $1973, \mathrm{H}$. Taylor reported that the site had become densely invaded. In $1996 \mathrm{~A}$. cyclops formed an impenetrable thicket over the entire 50 $\mathrm{m}^{2}$ quadrat.

While the diversity of the site has remained constant (seven species), the six indigenous taxa now cover less than $5 \%$ of its area. The only species to persist between surveys were Felicia fruticosa and Exomis microphylla, which grow on the coastal edge of the site and the tree species Tarchonanthus camphoratus. However, most of the original $T$. camphoratus thicket which grew just outside of the site has been eliminated as a direct result of invasion by $A$. cyclops (Figure 16).

Within less than 30 years $A$. cyclops has virtually eliminated the vegetation of this site and much of this geographically restricted community in the south of the Reserve. If it were not for the intensive and highly effective alien management programme administered by Reserve staff over the last 15 years, a far greater proportion of the Reserve's vegetation would have been similarly impacted by alien plants.

\section{CONCLUSIONS}

The vegetation of the CGHNR has undergone considerable change over the last 30 years. On average there has been a temporal turnover in species of $40 \%$ across the entire Reserve. There was a negative relationship between post-fire vegetation age and species diversity in both the 1966 and 1996 data sets. In proteoid fynbos the early post-fire succession was characterized by a predominance of resprouting graminoids, and ephemeral species which live for less than five years. After five years the vegetation composition stabilizes and is generally dominated by an overstorey proteoid layer. While predictions from moister inland localities suggest that fire-free intervals in excess of 30 years should result in the establishment of thicket patches, fynbos communities persisted even after 50 years in the Reserve. Thicket and forest development is much slower in the dry and windy southern Cape Peninsula than in the wetter mountain ranges. Coastal thicket communities maintain a stable composition and relative cover in the absence of fire. Short fire frequencies ( $<5$ years) favoured fast-maturing and sprouting species, while long fire-free intervals ( $>30$ years) resulted in high intensity fires which favoured myrmecochorous Proteaceae and negatively impacted serotinous Proteaceae. The common non-sprouting serotinous proteoid shrub, Leucadendron laureolum showed a high degree of spatial mobility over the sampling period. However, despite its considerable changes in distribution, the abundance and number of sites occupied by this species remained constant at the landscape scale over the last 30 years. Stands of alien plants have impacted large areas of natural vegetation in the Reserve. However, evidence from this study suggests that the natural flora is recovering well after clearing of alien stands. The threat posed by alien plants on the natural vegetation has been considerably reduced over the last 30 years.

Thus, while some of this change can be traced to human interference (prescribed burning and alien plants), most is a result of natural colonization and extinction. Temporal diversity resulting from high levels of colonization and extinction after patchy fires contributes to the high species diversity in fynbos systems.

\section{ACKNOWLEDGEMENTS}

Our grateful thanks are due to the Western Cape Regional Services Council for permission to undertake research in the Cape of Good Hope Nature Reserve. Thanks also to the management staff of the CGHNR, especially $\mathrm{Mr} \mathrm{R}$. Erntzen who provided past management records and useful interpretative discussions. Many thanks to W. Bond. B. Lamont and P. Zedler for comments on an earlier version of this manuscript. This research was financially supported by the Foundation for Research and Development and Pew Charitable Trusts.

\section{Footnote}

Since the submission of this manuscript, Hugh Taylor has passed away. His co-authors would like to acknowledge Hugh's pioneering research in fynbos, particularly his meticulous research in the Cape of Good Hope Nature Reserve, and his foresight in establishing the permanent plots used in this study.

\section{REFERENCES}

ACOCKS. J.P.H. 1975. Veld types of South Africa. Memoirs of the Botanical Survey of South Africa No. 40.

ARNOLD. T.H. \& DE WET, B.C. 1993. Plants of southern Africa: names and distribution. Memoirs of the Botanical Survey of South Africa No. 62: 1-825.

BOND, W.J. 1980. Fire and senescent fynbos in the Swartberg. south em Cape. South African Forestry Journal 114: 68-71.

BOND. W.J., LE ROLX. D. \& ERNTZEN. R. 1990. Fire intensity and regeneration of myrmecochorous Proteaceae. South African Journal of Botany 56: 326-330.

BROWN, PJ., MANDERS, PT. BANDS, D.P. KRUGER, FJ. \& ANDRAG, R.H. 1991. Prescribed burning as a conservation management practise: a case history from the Cederberg Mountains, Cape Province. South Africa. Biological Conservation 56: $133-150$.

CAMPBELL. B.M. 1985. A classification of the mountain vegetation of the fynbos biome. Memoirs of the Botanical Suney of South Africa No. 50: 1-115

CAMPBELL. B.M. \& VAN DER MEULEN. F. 1980. Patterns of plant species diversity in fynbos. Vegetatio $43: 43-47$

CONNEL, J.H. \& SLAYTER, R O. 1977. Mechanisms of succession in natural communities and their role in community stability and organisation. American Naturalist 111: 1119-1144.

COWLING. R.M. 1987. Fire and its role in coexistence and speciation in Gondwana shrublands. South African Journal of Science 83 $106-111$.

COWLING, R.M. \& GXABA. T. 1990). Effects of a fynbos overstorey shrub on understorey community structure: implications for the maintenance of community-wide species-richness. South African Journal of Ecology 1: 1-7

COWLING. R.M. \& HOLMES, P.M. 1992. Flora and vegetation. In R.M. Cowling. The ecology of fintos. Nutrients. fire and diver sit: 23-61. Oxford University Press, Cape Town.

COWLING, R.M. KIRKWOOD. D. MIDGILY. J.J \& PIERCE. S M. 1997 . Invasion and persistence of bird-dispersed. subtropi cal thicket and forest species in tire-prone fynbos. Journal of Vegetation Science 8: $475-488$. 
COWLING. R.M. \& PIERCE, S.M. 1988. Secondary succession in coastal dune fynbos: variation due to site and disturbance. Vegetatio 76: 131-139.

DODD, M., SILVERTOWN, J., MCVONWAY. K.. POTTS, J. \& CRAWLEY, M. 1995 . Community stability: a 60-year record of trends and outbreaks in the occurrence of species in the Park Grass Experiment. Journal of Ecology 83: 277-285.

ELPHICK. R. 1977. Kraal and castle: Khoikhoi and the founding of white South Africa. Yale University Press. London.

ESLER. K.J. \& COWLING, R.M. 1990. Effects of density on the reproductive output of Protea lepidocarpodendron. South African Journal of Botany 56: 29-33

FOJT. W. \& HARDING. M. 1995. Thirty years of change in the vegetation communities of three valley mires in Suffolk. England. Journal of Applied Ecology 32: 561-577.

FRASER. M. (in press). Bishops and baboons: a guide to the wildlife of the Cape of Good Hope Nature Resene.

FRASER. M. \& MCMAHON, L. 1995. Between two shores. Flora and fauna of the Cape of Good Hope. David Phillip Publishers, Cape Town.

HOFFMAN. M.T. \& COWLING. R.M. 1990. Vegetation change in the semi-arid Karoo over the last 2(0) years: an expanding Karoofact or fiction? South African Journal of Science 86: 286-294.

HOFFMAN, M.T.. MOLL. E.J. \& BOUCHER. C. 1987. Post-fire succession at Pella, a South African lowland fynbos site. South African Journal of Botany 53: 370-374.

HOLMES. P.M. \& COWLING. R.M. 1997. The effects of invasion by Acacia saligna on the guild structure and regeneration capabilities of South African fynbos shrublands. Journal of Applied Ecology 34: 317-332

KENT. M. \& COKER. P. 1992. Vegetation description and analysis. Belhaven Press, London.

KRUGER. F.J. 1984. Patterns of vegetation and climate in the Mediterranean zone of South Africa. Actualises Botaniques 131: 213-225.

KRUGER. F.J. 1987. Succession after fire in selected funbos communities of the southwestern Cape. Ph.D. thesis. University of the Witwatersrand.

1.E MAITRE. D.C. 1986. Kogelberg season of hurn trial IV. Effects of fire season and intensity on post-fire understorey growth. Unpublished report. Jonkershoek Forestry Research Centre.

L.E MAITRE. D.C. 1988. The effects of parent density and season of burn on the regeneration of Leucadendron laureolum (Proteaceae) in the Kogelherg. South African Journal of Botany 54: $581-584$

LE MAITRE. D.C \& MIDGI.EY. J.J. 1992. Plant reproductive ecology. In R.M. Cowling. The ecologv of finbes. Nutrients, fire and diversity: 135-174. Oxford University Press, Cape Town.

MACDONAL.D. I.A.W. CLARK. D.L. \& TAYLOR. H.C. 1989. The history and effects of alien plant control in the Cape of Gord Hope Nature Reserve. 1941-1987. South African Joumal of Botan: 55: 56,57

MACDONAL.D. I.A.W \& RICHARISSON, D.M. 1986. Alien species in terrestrial ecosystems of the fyntos biome. In I.A.W Macdonald. K.J. Kruger \& A A. Ferrar. The ecology and man agement of hiological invasions in southerm Africa: 77-91 Oxford University Press, Cape Town

MANDERS. PT \& RICHARISSON, D.M1 1992. Colonisation of Cape Fynbos communities by forest species. Forest Ecology and Management 48: 277-293.

MIDGLEY, J.J. 1989. Season of bum of serotinous Proteaceate: a criti cal review and further data. South A frican Joumal of Botans 55 $165-170$.

MIDGiLEY, J.J. ENRIGHT, N.J \& COWLING R M 1998 Co-exis tence. demography and distribution patterns of two co-oceurring ecologically equivalent fynbos Proteaceac species Ausiralian Journal of Bolani 46: 505-510
MINNICH, R.A., BARBOUR. M.G., BURK. J.H. \& FERNAU, R.F 1995. Sixty years of change in Californian conifer forests of San Bernardino Mountains. Consenution Biology 9: 902-914.

O'CONNOR. T.G. \& ROUX. P.W. 1995. Vegetation changes (1949-71) in a semi-arid, grassy dwarf shrubland in the Karoo, South Africa: influence of rainfail variability and grazing by sheep. Joumal of Applied Ecology 32: 612-626.

PRIVETT. S.D.J. 1998. Determinants of pattern in funbos vegetation. Physical site factors, disturbance regime, species attributes and temporal change. M.Sc. (Botany) thesis. University of Cape Town.

RICHARDSON. D.M., MACDONALD. I.A.W. \& FORSYTH. G.G 1989. Reductions in plant species-richness under stands of alien trees and shrubs in the fynbos biome. South African Forestn Journal 149: 1-8

RICHARDSON, D.M., MACDONALD, I.A.W. HOLMES, P.M. \& COWLING, R.M. 1992. Plant and animal invasions. In R.M Cowling. The ecology of finbos. Nutrients. fire and diversin: 260-308. Oxford University Press. Cape Town.

RICHARDSON, D.M. \& VAN WILGEN. B.W. 1985. Effects of thirty five years of afforestation with Pinus radiata on the composition of mesic mountain fynbos near Stellenbosch. South African Journal of Botany 52: 309-315

ROSE. A.B., PLATT. K.H. \& FRAMPTON, C.M. 1995. Vegetation change over 25 years in a New Zealand short tussock grassland: effects of sheep grazing and exotic invasions. New Zealand Journal of Ecology 19: 163-174.

SCHWILK. D.W. KEELEY. J.E. \& BOND. W.J. 1997. The intermediate disturbance hypothesis does not explain fire and diversity patterns in fynbos. Plant Ecology 132: 77-84.

TAYLOR. H.C. 1969. A vegetation survey of the Cape of Good Hope Nature Resenve. M.Sc. thesis. University of Cape Town.

TAYLOR. H.C. 1978. Capensis. In M.J.A. Werger. Biogeography and ecology of southern Africa: 173-223. Junk. The Hague.

TAYLOR. H.C. 1983. The vegetation of the Cape of Good Hope Nature Reserve. Bothalia 14: 779-784.

TAYLOR. H.C. 1984a. A vegetation survey of the Cape of Good Hope Nature Reserve. I. The use of association-analysis and BraunBlanquet methods. Bothalia 15: 245-258.

TAYLOR. H.C. 1984b. A vegetation survey of the Cape of Good Hope Nature Reserve. II. Descriptive account. Bothalia 15: 259-291.

TAYLOR. H.C. \& MACDONALD. A. 1985. Invasive alien woody plants in the Cape of Good Hope Nature Reserve. I. Results of a first survey in 1966. South African Journal of Botany 51 $14-20$

TAYLOR. H.C. MACDONALD. A. \& MACDONALD. I.A.W. 1985 Invasive alien woody plants in the Cape of Good Hope Nature Reserve. II. Results of a second survey from 1976 to 1980. South African Journal of Botany 51: 21-29.

VAN WILGEN, B.W. 1981. Some effects of fire frequency on fynbos plant community composition and structure at Jonkershoek. Stellenbosch. South African Forestry Joumal 118: 42-55

VAN WILGEN. B.W. \& FORSYTH. G.G. 1992. Regeneration strategies in fynbos plants and their influence on the stability of com munity houndaries after fire. In B.W. van Wilgen. D.M Richardson. F.J. Kruger \& H.J. van Hensbergen. Fire in South African mouniain funbos: 1-20. Springer-Verlag. Berlin.

VAN WILGEN. B.W KRUGER. F.J. 1981. Observations on the effects of fire in mountain fynbos at Zachariashoek. Paarl. Joumal of South Africun Botany 47: 195-211.

VLOK. J.HJ. 1996. The role of overstorey proteoid shrubs in main raining species-richness in a southern Cape mountain finbos community. M.Sc. thesis. University of Natal. Pietermaritzburg.

WIENS. J.A 1986. Spatial scale and temporal variation in studies of shrubsteppe birds. In J. Diamond \& T.J. Case. Communirv ecology: 154 - 172. Harper \& Rou. New York.

WILLIAMS. IJ.M. 1972. A revision of the genus Leucadendron (Proteaceac). Contribusions to the Bolus Herharium 3: 1 - $4(1) 2$ 
APPENDIX 1.-Comparison of species composition in 81 sites in 1966 and 1996. Vegetation types abbreviated as follows: WET, wetlands; WRF. wet restioid fynbos: MOP, mesic oligotrophic proteoid fynbos; SED, sedgeland; SPF, sandplain proteoid fynbos: DAF, dune asteraceous fynbos; CSA, coastal scree asteraceous fynbos

\begin{tabular}{|c|c|c|c|c|c|c|c|c|c|c|c|}
\hline $\begin{array}{l}\text { Site } \\
\text { no. }\end{array}$ & $\begin{array}{l}\text { Vegetation } \\
\text { type }\end{array}$ & $\begin{array}{c}\text { No. spp. } \\
1966\end{array}$ & $\begin{array}{l}\text { No. spp. } \\
1996\end{array}$ & $\begin{array}{l}\text { No. spp. } \\
\text { shared }\end{array}$ & $\begin{array}{l}\text { Sorenson's } \\
\text { coefficient } \\
\times 100\end{array}$ & $\begin{array}{l}\text { Site } \\
\text { no. }\end{array}$ & $\begin{array}{l}\text { Vegetation } \\
\text { type }\end{array}$ & $\begin{array}{c}\text { No. spp. } \\
1966\end{array}$ & $\begin{array}{c}\text { No. spp. } \\
1996\end{array}$ & $\begin{array}{l}\text { No. spp. } \\
\text { shared }\end{array}$ & $\begin{array}{c}\text { Sorenson's } \\
\text { coefficient } \\
\times 100\end{array}$ \\
\hline 1 & MOP & 51 & 46 & 33 & 68.04 & 55 & WRF & 33 & 29 & 19 & 61.30 \\
\hline 2 & MOP & 43 & 30 & 24 & 65.75 & 56 & WRF & 17 & 27 & 10 & 45.46 \\
\hline 3 & MOP & 68 & 45 & 35 & 61.95 & 57 & MOP & 32 & 45 & 27 & 70.13 \\
\hline 4 & MOP & 28 & 24 & 14 & 53.85 & 58 & WET & 18 & 25 & 11 & 51.16 \\
\hline 8 & MOP & 79 & 50 & 41 & 63.57 & 59 & MOP & 42 & 61 & 32 & 62.14 \\
\hline 9 & MOP & 73 & 50 & 41 & 66.68 & 60 & $\mathrm{CSA}$ & 15 & 11 & 7 & 53.85 \\
\hline 10 & MOP & 50 & 53 & 31 & 60.19 & 61 & MOP & 47 & 46 & 26 & 55.91 \\
\hline 12 & MOP & 64 & 47 & 32 & 57.66 & 62 & MOP & 25 & 47 & 22 & 61.11 \\
\hline 13 & WRF & 44 & 34 & 26 & 66.67 & 63 & MOP & 36 & 43 & 25 & 63.3 \\
\hline 14 & WRF & 44 & 32 & 21 & 55.24 & 64 & WRF & 36 & 40 & 27 & 71.05 \\
\hline 15 & WRF & 66 & 27 & 23 & 49.46 & 65 & WRF & 12 & 22 & 8 & 47.06 \\
\hline 16 & WRF & 52 & 29 & 23 & 56.79 & 66 & MOP & 39 & 37 & 29 & 76.32 \\
\hline 17 & WRF & 30 & 27 & 19 & 66.67 & 67 & MOP & 49 & 42 & 35 & 76.93 \\
\hline 18 & WRF & 18 & 14 & 8 & 50.00 & 68 & DAF & 25 & 26 & 15 & 58.82 \\
\hline 19 & WRF & 27 & 28 & 15 & 54.55 & 70 & MOP & 49 & 40 & 23 & 51.69 \\
\hline 21 & MOP & 37 & 32 & 24 & 69.57 & 71 & MOP & 35 & 41 & 28 & 73.68 \\
\hline 22 & WRF & 34 & 34 & 25 & 73.53 & 72 & WRF & 36 & 27 & 17 & 53.97 \\
\hline 23 & MOP & 26 & 23 & 16 & 65.31 & 73 & MOP & 39 & 37 & 23 & 60.53 \\
\hline 24 & MOP & 46 & 44 & 27 & 60.0 & 74 & MOP & 39 & 31 & 21 & 60.00 \\
\hline 25 & DAF & 14 & 18 & 7 & 43.75 & 75 & MOP & 75 & 61 & 46 & 67.65 \\
\hline 27 & MOP & 52 & 53 & 40 & 76.19 & 76 & MOP & 71 & 50 & 39 & 64.46 \\
\hline 28 & MOP & 38 & 49 & 29 & 66.67 & 78 & WRF & 24 & 24 & 16 & 66.67 \\
\hline 29 & WRF & 15 & 17 & 9 & 56.25 & 79 & WRF & 58 & 41 & 33 & 66.67 \\
\hline 30 & MOP & 52 & 60 & 39 & 69.64 & 80 & $\mathrm{CSA}$ & 25 & 20 & 16 & 71.11 \\
\hline 31 & MOP & 51 & 51 & 43 & 84.31 & 81 & MOP & 44 & 31 & 25 & 66.67 \\
\hline 34 & MOP & 45 & 61 & 41 & 77.36 & 82 & WRF & 74 & 48 & 39 & 63.93 \\
\hline 36 & MOP & 41 & 46 & 31 & 71.26 & 83 & WRF & 14 & 13 & 8 & 59.26 \\
\hline 37 & WRF & 34 & 43 & 25 & 64.96 & 84 & MOP & 33 & 54 & 29 & 66.67 \\
\hline 38 & WRF & 20 & 20 & 13 & 65.00 & 86 & MOP & 51 & 41 & 28 & 60.87 \\
\hline 39 & MOP & 51 & 54 & 36 & 68.57 & 87 & MOP & 73 & 66 & 47 & 67.63 \\
\hline 40 & MOP & 35 & 46 & 23 & 56.79 & 88 & MOP & 24 & 30 & 17 & 62.96 \\
\hline 42 & MOP & 56 & 41 & 26 & 53.61 & 89 & MOP & 24 & 21 & 13 & 57.78 \\
\hline 44 & MOP & 61 & 60 & 40 & 66.12 & 90 & DAF & 20 & 18 & 15 & 78.95 \\
\hline 45 & MOP & 51 & 58 & 38 & 69.73 & 91 & SED & 11 & 16 & 6 & 44.44 \\
\hline 46 & WRF & 28 & 32 & 20 & 66.67 & 92 & MOP & 39 & 42 & 21 & 51.85 \\
\hline 47 & WET & 6 & 15 & 5 & 47.62 & 94 & SPF & 27 & 36 & 22 & 69.84 \\
\hline 48 & WRF & 20 & 15 & 9 & 51.43 & 95 & MOP & 27 & 20 & 11 & 46.81 \\
\hline 49 & WRF & 21 & 43 & 19 & 59.375 & 97 & $\mathrm{CSA}$ & 4 & 6 & 3 & $(x)(x)$ \\
\hline 50 & WRF & 22 & 41 & 14 & +4.44 & 98 & MOP & 46 & 56 & 33 & 64.71 \\
\hline \multirow[t]{2}{*}{54} & MOP & 36 & 28 & 15 & 46.88 & 99 & MOP & 38 & 38 & 24 & 63.16 \\
\hline & & & & & & $10 x)$ & MOP & 52 & 32 & 24 & 57.14 \\
\hline
\end{tabular}


APPENDIX 2.-The fire histories of all sites used in this study

\begin{tabular}{|c|c|c|c|c|c|}
\hline $\begin{array}{l}1996 \\
\text { site no. }\end{array}$ & $\begin{array}{l}\text { Taylor's } \\
\text { site no. }\end{array}$ & Fire history & $\begin{array}{l}1996 \\
\text { site no. }\end{array}$ & $\begin{array}{l}\text { Taylor's } \\
\text { site no. }\end{array}$ & Fire history \\
\hline 1 & 1 & 1958, summer 1975, summer 1986 & 43 & 56 & 1952. autumn 1977. winter 1988 \\
\hline 2 & 2 & 1958, summer 1975, summer 1986 & 44 & 57 & 1947. autumn 1975. autumn 1989 \\
\hline 3 & 3 & 1958. summer 1975, summer 1986 & 45 & 58 & 1947. autumn 1975. autumn 1989 \\
\hline 4 & 4 & 1948. summer 1975, summer 1986 & 46 & 59 & 1951, autumn 1975. summer 1992 \\
\hline 5 & 7 & 1961. summer 1975, summer 1986 & 47 & 60 & No fires \\
\hline 6 & 8 & 1963, summer 1975, summer 1986 & 48 & 61 & 1959. summer 1991 \\
\hline 7 & 9 & 1963. summer 1975. summer 1986 & 49 & 62 & 1947. autumn 1979. winter 1988 \\
\hline 8 & 10 & 1963, summer 1975, summer 1986 & 50 & 63 & 1947. autumn 1979. winter 1988 \\
\hline 9 & 12 & 1963, summer 1975 , summer 1986 & 51 & 64 & 1951. autumn 1979. winter 1988 \\
\hline 10 & 13 & 1963, summer 1975, summer 1986 & 52 & 65 & 1951. autumn 1983, autumn 1989 \\
\hline \multirow[t]{3}{*}{11} & 14 & 1963, winter 1970, winter 1973, winter 1976. & 53 & 66 & 1951. autumn 1983 \\
\hline & & winter 1979, winter 1982 , winter 1985 . winter & 54 & 67 & 1946. autumn 1983 \\
\hline & & 1988 & 55 & 68 & 1963. summer 1991 \\
\hline 12 & 15 & 1963, summer 1986 & 56 & 70 & - 1964. summer 1991 \\
\hline 13 & 16 & 1963. summer 1986 & 57 & 71 & 1954. spring 1968. winter 1981. autumn 1989 \\
\hline 14 & 17 & 1963. summer 1975. summer 1986 & 58 & 72 & 1941. spring 1968. autumn 1983 \\
\hline 15 & 18 & 1963, summer 1975, summer 1986 & 59 & 73 & 1954. spring 1968, autumn 1983 \\
\hline 16 & 19 & 1949. summer 1986 & 60 & 74 & No fires \\
\hline 17 & 21 & 1951. autumn 1977. summer 1986 & 61 & 75 & -1965. autumn 1979. summer 1991 \\
\hline 18 & 22 & 1945, summer 1975, summer 1986 & 62 & 76 & - 1965. winter 1981. summer 1991 \\
\hline 19 & 23 & 1951, summer 1975, summer 1986 & 63 & 77 & 1953. autumn 1974, winter 1981. summer 1991 \\
\hline 20 & 24 & 1962. summer 1975, summer 1986 & 64 & 78 & 1961. bushcut 1966, autumn 1983, summer 1992 \\
\hline 21 & 25 & 1935?, summer 1986. summer 1991 & 65 & 79 & 1946. spring 1968, autumn 1983 \\
\hline 22 & 27 & 1945, summer 1977. summer 1986 & 66 & 80 & No fires \\
\hline 23 & 28 & 1945, summer 1977, summer 1986 & 67 & 81 & No fires \\
\hline 24 & 29 & 1956. summer 1975. summer 1986 & 68 & 82 & 1965. winter 1981, summer 1991 \\
\hline 25 & 30 & 1948. summer 1975, summer 1986 & 69 & 83 & 1958. winter 1981. summer 1991 \\
\hline 26 & 31 & 1955. summer 1975. summer 1986 & 70 & 84 & 1958. winter 1981. summer 1991 \\
\hline 27 & 34 & 1953. summer 1991 & 71 & 85 & No fires \\
\hline 28 & 36 & 1951, summer 1977. summer 1986 & 72 & 86 & - 1965. winter 1981. summer 1991 \\
\hline 29 & 37 & 1940. summer 1977. summer 1986. winter 1988 & 73 & 87 & - 1965. winter 1981. summer 1991 \\
\hline 30 & 38 & 1954. autumn 1975. summer 1986 & 74 & 88 & 1955. winter 1981, summer 1991 \\
\hline 31 & 39 & 1945. summer 1975. summer 1986 & 75 & 89 & 1951 , winter 1966 \\
\hline 32 & 40 & 1955. summer 1975. summer 1986 & 76 & 90 & No fires \\
\hline 33 & 42 & 1965. summer 1975, summer $1986.1992 ?$ & 77 & 91 & 1946. winter 1981. summer 1991 \\
\hline 34 & 44 & 1957. summer 1991 & 78 & 92 & 1942. summer 1991 \\
\hline 35 & 45 & 1957. summer 1991 & 79 & 93 & 1946. summer 1991 \\
\hline 36 & 46 & 1951. autumn 1979. winter 1988 & 80 & 94 & 1951. autumn 1992 \\
\hline 37 & 47 & 1948. autumn 1977. winter 1988 & 81 & 95 & No fires \\
\hline 38 & 48 & 1956. autumn 1975. autumn 1977. autumn 1989 & 82 & 97 & No fires \\
\hline 39 & 44 & 1948. autumn 1975. autumn 1989 & 83 & 98 & 1946. autumn 1975. summer 1992 \\
\hline 40 & 50 & 1958. summer 1975. autumn 1989 & 84 & 99 & No fires \\
\hline 41 & 54 & 1952, autumn 1979 & 85 & $\mathrm{I}(0)$ & No fires \\
\hline 42 & 55 & 1952. autumn 1979. winter 1988 & & & \\
\hline
\end{tabular}

